\title{
Differential roles of PPAR $\gamma$ vs TR4 in prostate cancer and metabolic diseases
}

\author{
Su Liu ${ }^{1, *}$, Shin-Jen Lin ${ }^{1, *}$, Gonghui $\mathrm{Li}^{3, *}$, Eungseok Kim ${ }^{4}$, Yei-Tsung Chen ${ }^{5}$, \\ Dong-Rong Yang', M H Eileen Tan ${ }^{2}$, Eu Leong Yong ${ }^{2}$ and Chawnshang Chang ${ }^{1,6}$
}

\author{
${ }^{1}$ George Whipple Laboratory for Cancer Research, Departments of Pathology, Urology, Radiation Oncology, \\ and The Wilmot Cancer Center, University of Rochester Medical Center, Rochester, New York 14642, USA \\ ${ }^{2}$ Department of Obstetrics and Gynecology, National University of Singapore, Singapore, Singapore \\ ${ }^{3}$ Chawnshang Chang Liver Cancer Center and Department of Urology, Sir Run Run Shaw Hospital, \\ Zhejiang University, Hangzhou 310016, China \\ ${ }^{4}$ Department of Biological Sciences, Chonnam National University, Youngbong, Buk-Gu, Gwangju 500-757 Korea \\ ${ }^{5}$ Cardiovascular Research Institute, National University Health System and The Department of Medicine, \\ Yong Loo Lin School of Medicine, National University of Singapore, Singapore \\ ${ }^{6}$ Sex Hormone Research Center, China Medical University/Hospital, Taichung 404, Taiwan \\ *(S Liu, S-J Lin and G Li are co-first authors)
}

Correspondence should be addressed to C Chang

Email

chang@urmc.rochester.edu

\begin{abstract}
Peroxisome proliferator-activated receptor $\gamma(\operatorname{PPAR} \gamma, \mathrm{NR} 1 \mathrm{C} 3)$ and testicular receptor 4 nuclear receptor (TR4, NR2C2) are two members of the nuclear receptor (NR) superfamily that can be activated by several similar ligands/activators including polyunsaturated fatty acid metabolites, such as 13-hydroxyoctadecadienoic acid and 15-hydroxyeicosatetraenoic acid, as well as some anti-diabetic drugs such as thiazolidinediones (TZDs). However, the consequences of the transactivation of these ligands/activators via these two NRs are different, with at least three distinct phenotypes. First, activation of PPAR $\gamma$ increases insulin sensitivity yet activation of TR4 decreases insulin sensitivity. Second, PPAR $\gamma$ attenuates atherosclerosis but TR4 might increase the risk of atherosclerosis. Third, PPAR $\gamma$ suppresses prostate cancer (PCa) development and TR4 suppresses prostate carcinogenesis yet promotes PCa metastasis. Importantly, the deregulation of either PPAR $\gamma$ or TR4 in PCa alone might then alter the other receptor's influences on PCa progression. Knocking out PPAR $\gamma$ altered the ability of TR4 to promote prostate carcinogenesis and knocking down TR4 also resulted in TZD treatment promoting PCa development, indicating that both PPAR $\gamma$ and TR4 might coordinate with each other to regulate PCa initiation, and the loss of either one of them might switch the other one from a tumor suppressor to a tumor promoter. These results indicate that further and detailed studies of both receptors at the same time in the same cells/organs may help us to better dissect their distinct physiological roles and develop better drug(s) with fewer side effects to battle PPAR $\gamma$ - and TR4-related diseases including tumor and cardiovascular diseases as well as metabolic disorders.
\end{abstract}

\section{Key Words}

- prostate

- molecular genetics
Endocrine-Related Cancer (2014) 21, R279-R300
(C) 2014 Society for Endocrinology Printed in Great Britain
Published by Bioscientifica Ltd. 


\section{Introduction: the history of cloning/isolation of PPAR $\gamma$ and testicular receptor 4}

Peroxisome proliferator-activated receptor $\gamma$ (PPAR $\gamma$, NR1C3) was first cloned from Xenopus and mice as an orphan nuclear receptor (NR) on the basis of sequence homology to PPAR $\alpha$ (NR1C1) (Dreyer et al. 1992, Zhu et al. 1993), which could induce peroxisome proliferation in rodent hepatocytes (Issemann \& Green 1990). Early studies linked PPAR $\gamma$ to adipocyte function because of its high levels of expression in adipose tissues and its ability to stimulate adipocyte differentiation in cultured fibroblasts (Tontonoz et al. $1994 a, b)$. Subsequent studies identified some natural adipogenic regulators, polyunsaturated fatty acids (PUFAs), such as eicosapentaenoic acid (EPA), linolenic acid (LA), and their metabolites, such as $8(S)$ hydroxyeicosatetraenoic acid (8(S)HETE) and 15-deoxy- $\Delta 12,14$-prostaglandin $\mathrm{J}_{2},\left(15 \mathrm{~d}-\mathrm{PGJ}_{2}\right)$ as natural ligands/activators of PPAR $\gamma$ (Forman et al. 1995, Kliewer et al. 1995, Krey et al. 1997). Furthermore, rosiglitazone, one of the thiazolidinediones (TZDs), a class of antidiabetic medicines, was found to bind to PPAR $\gamma$ with a high affinity (Lehmann et al. 1995). Since then, more PPAR $\gamma$ selective agonists have been developed to battle type 2 diabetes (Staels \& Fruchart 2005).

In contrast, testicular receptor 4 (TR4, NR2C2), another member of the NR superfamily, was initially cloned from human and rat testis (Chang et al. 1994), and it shares a high homology (65\%) with one of the first identified orphan NRs, TR2 (NR2C1) (Chang \& Kokontis 1988, Chang et al. 1989). Results from functional studies of TR4 expression patterns (Chang et al. 1994, Hirose et al. 1994), modulation of target genes (Liu et al. 2007), and TR4 knockout (TR4 ${ }^{-/-}$) mice (Collins et al. 2004, Mu et al. 2004, Chen et al. 2005, 2008, Zhang et al. 2007) indicated that TR4 might play important roles in energy homeostasis as a lipid sensor, as well as in neuronal development and fertility. More importantly, from those extensive in vivo function studies, Xie et al. (2009) discovered that the PUFA metabolites, 15-hydroxyeicosatetraenoic acid (15-HETE) and 13-hydroxyoctadecadienoic acid (13-HODE) as well as rosiglitazone, could function as ligands/activators to transactivate TR4 to a degree similar to PPAR $\gamma$. These unexpected results link these two different NRs and raise some very interesting questions. Why does our body need two different NRs that can be activated by similar ligands/activators? Do the ligands/ activators bind to them with preferences depending on the context of tissues/cells or diurnal time points? Do they have similar or distinct physiological functions? Do we need to re-evaluate those anti-diabetic drugs that were initially intended to specifically target PPAR $\gamma$ if they actually also activate TR4? Does TR4 activation by those drugs cause any side effects? What are the potential effects on the development of new anti-diabetic medicines?

This review summarizes a comprehensive comparison of PPAR $\gamma$ and TR4 in terms of their sequences, structures, tissue distributions, target genes, ligands/activators, and physiological functions. The potential significance and the possible pathophysiological consequences of the activation of two different NRs by similar ligands/ activators will also be discussed.

\section{Structure analysis and tissue distribution of PPAR $\gamma$ and TR4}

\section{PPAR $\gamma$ and TR4 NR family members}

Other than PPAR $\gamma$, there are two related members in the PPAR family, PPAR $\alpha$ (NR1C1) and PPAR $\delta$ (NR1C2) (Desvergne \& Wahli 1999). PPAR $\alpha$ is expressed in most tissues, with higher expression levels in brown adipose tissue and liver. PPAR $\gamma$ is mainly expressed in adipose tissue and moderately expressed in the kidney and liver (Kersten et al. 2000). PPAR $\delta$ is ubiquitously expressed in all tissues with the highest expression in the gut and placenta (Bookout et al. 2005).

All three PPARs can heterodimerize with retinoid $\mathrm{X}$ receptor (RXR) to modulate expression of their target genes (Ferre 2004). The ligand recognition often overlaps among the PPARs. All the three PPARs can be activated by PUFAs with affinities in the following order: PPAR $\alpha>$ $\operatorname{PPAR} \gamma>\operatorname{PPAR} \delta$ (Bragt \& Popeijus 2008).

Three PPAR $\gamma$ transcripts, termed PPAR $\gamma 1$, PPAR $\gamma 2$, and PPAR $\gamma 3$, are derived from the PPAR $\gamma$ (PPARG) gene by differential promoter usage (Fajas et al. 1997). PPAR $\gamma 1$ is broadly expressed and both PPAR $\gamma 2$ and PPAR $\gamma 3$ are highly expressed in adipose tissue. PPAR $\gamma 3$ is also expressed in macrophages. The $P P A R \gamma 1$ and $P P A R \gamma 3$ mRNAs yield the same protein product. However, the $P P A R \gamma 2$ mRNA gives rise to a protein containing an additional 28 amino acids at the $\mathrm{N}$ terminus. To date, no functional differences have been found between the PPAR $\gamma$ isoforms.

TR2, which is closely related to TR4, was one of the first identified orphan NRs (Chang \& Kokontis 1988). TR2 expression is widespread in various mouse tissues with highest abundance in the testis (Bookout et al. 2005). The ligands/activators of TR2 remains unknown, while androgen (Ideta et al. 1995) has been reported to repress its expression.

Published by Bioscientifica Ltd. 
The physiological function of TR2 remains unclear. It was categorized as belonging to the NR cluster that controls lipid metabolism and energy homeostasis by hierarchical, unsupervised clustering based on tissue expression (Bookout et al. 2006). However, TR2 knockout (TR2 $\left.{ }^{-/-}\right)$mice have a normal phenotype, yet TR4/TR2 double knockout (TR $4^{-/}$/ $T R 2^{-/}$) mice die at the embryonic stage, indicating a functional overlap between TR4 and TR2 (Shyr et al. 2009).

\section{Sequence homology between PPAR $\gamma$ and TR4}

Sequence analyses show that all three members of the PPAR family have a highly conserved DNA-binding domain (DBD) encoding two zinc fingers, and a ligand-binding domain (LBD) in the C-terminal region of the protein. Sequence comparison among these three PPARs using the EMBOSS Pairwise Alignment Algorithms (http://www.ebi. ac.uk/Tools/emboss/align/index.html) found that PPAR $\gamma$ shares an overall $51.6 \%$ homology with PPAR $\alpha$ (with $84.0 \%$ in the DBD and $68.8 \%$ in LBD), the while the similarity between PPAR $\gamma$ and PPAR $\delta$ is $48.4 \%$ (with $81.6 \%$ homology in the DBD and $72.3 \%$ in the LBD) (Fig. 1A).

Sequence comparison between TR4 and TR2 demonstrated that they share a $60.4 \%$ identity in overall structure (Fig. 1B), with a $72.4 \%$ homology in DBD and a $62.4 \%$ homology in LBD.

Amino acid sequence comparison between TR4 and PPAR $\gamma$ found that they share an overall $20.2 \%$ identity (134 out of 665 amino acids), with the similarity of their
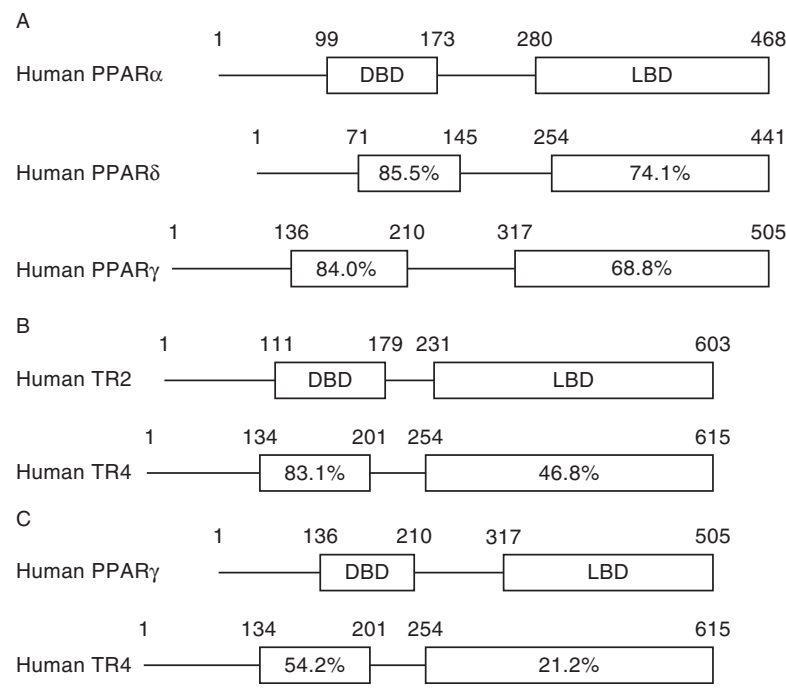

Figure 1

(A) Protein sequence alignment of PPAR $\alpha$, PPAR $\delta$ and PPAR $\gamma$ using EMBOSS. (B) Protein sequence alignment of TR2 and TR4 using EMBOSS. (C) Protein sequence alignment of PPAR $\gamma$ and TR4 using EMBOSS.
DBDs reaching $54.2 \%$. The similarity of the LBDs between these two receptors is $21.2 \%$.

Based on the relatively lower sequence homology of LBD between PPAR $\gamma$ and TR4, it is not easy to predict whether these two NRs may similar ligands/activators. For example, the androgen receptor (AR) and estrogen receptor (ER) have 26.3\% identity in their LBDs and they do not share their ligands. This interesting question may need detailed 3D structure analyses of PPAR $\gamma$ and TR4 to explain how they can share similar ligands/activators with this low LBD homology.

\section{Tissue distribution of PPAR $\gamma$ and TR4}

PPAR $\gamma$ is expressed in all tissues with the highest expression in white and brown adipose tissues (Bookout et al. 2005), where it is the key orchestrator of the transcriptional cascade during adipocyte differentiation. Its expression is highest postprandially (Vidal-Puig et al. 1996), and its activation leads to upregulation of genes that mediate uptake and trapping of fatty acids. It is known that PPAR $\gamma$ controls the alternative activation of macrophages and improves insulin resistance (Odegaard et al. 2007). Selective activation of PPAR $\gamma$ in skeletal muscle protects mice from diet-induced insulin resistance (Amin et al. 2010). TR4 is ubiquitously expressed in all tissues examined (Bookout et al. 2006), with the highest expression in the CNS and testes. Interestingly, a recent study detected a similar expression pattern of TR4 and PPAR $\gamma$ in female mouse liver hepatocytes, liver endothelial cells, and Kupffer cells (Li et al. 2013), indicating that their expression might be regulated by the same stimuli. On the other hand, patterns of TR4 expression in four major metabolic tissues are rhythmic (Yang et al. 2006), which strongly indicates its importance in regulating metabolic homeostasis. PPAR $\gamma$ also shows a diurnal rhythmic expression pattern in white adipose tissue (WAT) and liver, where its expression peaks at zeitgeber time (ZT)16 and ZT8 respectively, while TR4 expression peaks at ZT4 in both tissues (Table 1).

The distinct diurnal expression pattern of PPAR $\gamma$ vs TR4 might provide the flexibility and specificity that allow these two NRs to function as energy and lipid sensors in response to stimuli to coordinately control metabolism.

\section{Transactivation of PPAR $\gamma$ and TR4 by natural and synthetic ligands}

\section{Natural ligands: PUFAs and their metabolites}

$\operatorname{PPAR} \gamma$ can be transactivated by a variety of lipophilic ligands, including long-chain PUFAs, such as EPA

Published by Bioscientifica Ltd. 
Table 1 The peak expression of TR4 and PPAR $\gamma$ in metabolic tissues. BAT, brown adipose tissue; WAT, white adipose tissue

\begin{tabular}{llll}
\hline \multicolumn{1}{c}{ Tissues } & TR4 & & PPAR \\
\cline { 1 - 1 } WAT & ZT4 & ZT16 \\
BAT & ZT0 & ZT8 \\
Liver & ZT4 & \\
Muscle & ZT12 & \\
\hline
\end{tabular}

(LA (Willson \& Wahli 1997, Nagy et al. 1998, Abdelrahman et al. 2005)), and their metabolites, including 9-HODE, 13-HODE, 12-HETE, 15-HETE (Willson \& Wahli 1997, Nagy et al. 1998, Abdelrahman et al. 2005) and 15d-PGJ 2 (Kliewer et al. 1995). More recently, two other prostaglandins, PG-H(1) and PG-H(2), were also reported to be weak ligands for PPAR $\gamma$ (Ferry et al. 2001).

A metabolite of arachidonic acid, $15 \mathrm{~d}-\mathrm{PGJ}_{2}$, was first discovered in 1983 (Fitzpatrick \& Wynalda 1983), and later in 1995, it was identified as an endogenous ligand for PPAR $\gamma$ (Forman et al. 1995, Kliewer et al. 1995). However, the concentration of $15 \mathrm{~d}-\mathrm{PGJ}_{2}$ required to stimulate PPAR $\gamma$ is generally in the micromolar range (Powell 2003), and Bell-Parikh et al. (2003) concluded that although $15 \mathrm{~d}-\mathrm{PGJ}_{2}$ could be generated in vivo, its physiological level is not sufficient to turn on PPAR $\gamma$. Thus, whether $15 \mathrm{~d}-\mathrm{PGJ}_{2}$ can be claimed to be an endogenous ligand for PPAR $\gamma$ remains debatable. Nevertheless, 15d$\mathrm{PGJ}_{2}$ is still the most potent and most commonly used natural agonist for PPAR $\gamma$ to date (Abdelrahman et al. 2005).

TR4 has been an orphan NR without any identified ligand since it was first cloned in 1994 (Chang et al. 1994). Interestingly, Xie et al. (2009) recently found that PPAR $\gamma$ ligands, including TZDs as well as the PUFA metabolites, 15-HETE and 13-HODE, might transactivate TR4 to a level similar to that observed for PPAR $\gamma$. This discovery was first inspired by the phenotypes found in $T R 4^{-/-}$mice, which display reduced fat mass, smaller adipocyte size, low glucose levels at birth and under fasting conditions, and improved insulin sensitivity (Liu et al. 2007, 2009, Xie et al. 2009, Kim et al. 2011). Further studies showed that TR4 might function as a fatty acid sensor via modulation of several key genes, such as CD36, SCD1, and PEPCK, which are involved in lipid metabolism and insulin sensitivity (Liu et al. 2007, 2009, Xie et al. 2009, Kim et al. 2011). We then screened many CD36 inducers and found that PUFA metabolites, such as 13-HODE and 15-HETE, could induce CD36 expression via transactivation of TR4. Protease peptide mapping assays further demonstrated that trypsin digestion patterns of TR4 were changed in the presence of 13-HODE or 15-HETE, indicating that the receptor conformation was changed due to the direct binding between TR4 and 13-HODE or 15-HETE (Xie et al. 2009). These ligands/activators were able to transactivate TR4 and PPAR $\gamma$ in a similar manner in the same cells, indicating that both TR4 and PPAR $\gamma$ may function as fatty acid sensors upon activation by these ligands/activators.

\section{Synthetic ligands: TZDs}

In addition to natural ligands, a wide range of synthetic $\operatorname{PPAR} \gamma$ agonists have been developed, including the TZDs, such as rosiglitazone, pioglitazone, ciglitazone, and troglitazone, that were widely used as anti-diabetic drugs (Quinn et al. 2008). In 1997, troglitazone was the first TZD to be approved for the treatment of patients with type 2 diabetes but was withdrawn from the market in 2000 following the emergence of a serious hepatotoxicity in some patients (Booth et al. 2000). Rosiglitazone and pioglitazone also have side effects including increased risk of heart attacks and bladder cancer (BCa) that caused the drugs to be placed under sales restrictions in the USA. TZDs were screened out via modulation of PPAR $\gamma$ transactivation that resulted in the alteration of expression of several key genes involved in glucose and lipid metabolism and energy balance (Hauner 2002). These TZDs may bind to PPAR $\gamma$ closely given their in vivo hypoglycemic potency (Abdelrahman et al. 2005) that increases the ability of insulin to suppress endogenous glucose production resulting in enhanced insulin sensitivity in adipose tissue (Nolan et al. 1994). However, clear evidence also indicate the existence of PPAR $\gamma$ independent effects of treatment with TZDs (Lecomte et al. 2008, Vandewalle et al. 2008). Finding that TZDs can also transactivate TR4 (Xie et al. 2009) may therefore raise a very interesting question of whether TZDs may yield differential effects via activating these two different NRs.

\section{Analysis of 3D structure via X-ray crystallography to distinguish ligand specificity of PPAR $\gamma$ and TR4}

X-ray crystallography has greatly improved our understanding of how NRs are activated by the binding of their specific ligands and the subsequent conformational changes (Nolte et al. 1998). The apo-PPAR $\gamma$ LBD possesses a canonical helical sandwich fold as seen in other NRs. Unlike other NRs, PPAR $\gamma$ has an additional $\alpha$-helix (designated H2), which creates a solvent-accessible channel between $\mathrm{H} 3$ and the $\beta$-strands, and this channel seems to serve as an entry to the ligand-binding pocket. The rosiglitazone-bound PPAR $\gamma$ has been detected as a homodimer (Nolte et al. 1998), and more recently, as a

Published by Bioscientifica Ltd. 
heterodimer with RXR $\alpha$ (Gampe et al. 2000), which might be more physiologically relevant. In both cases, only the S-isomer of rosiglitazone was found bound to PPAR $\gamma$, even though a racemic mixture was used in the crystallization. Consistent with this observation, ligand-binding data also indicate that only the S-isomer of rosiglitazone is a high-affinity ligand for PPAR $\gamma$.

The overall root-mean-square deviation between PPAR $\gamma$-LBD and TR4-LBD is 5.57, indicating that the overall conformation of these two proteins is different. Nonetheless, PPAR $\gamma$-LBD shares common structural characteristics with TR4-LBD. Structural comparison of both apo-PPAR $\gamma$ and apo-TR4 LBD structures reveals that the proximal half of the three layer helices is highly similar, suggesting that the helix sandwich fold is evolutionarily conserved between these two proteins (Fig. 2A).

Despite the similarity of the proximal halves of the LBDs between PPAR $\gamma$ and TR4, the ligand-binding pockets of the two receptors, which are located in the distal half of the LBD, vary greatly. The apo-PPAR $\gamma$ ligand binding cavity has a large T-shape pocket of $\sim 1300 \AA^{3}$ (Nolte et al. 1998). Unlike PPAR $\gamma$, the recently discovered apo-TR4 structure reveals an absence of a ligand-binding pocket (Zhou et al. 2011). The C-terminal part of helix 10 bends and collapses into the space where the ligand-binding pocket should be (Fig. 2B). The large pocket of the PPARs, as compared with that of TR4, allows these receptors to bind to diverse metabolites promiscuously and with a low affinity. Several studies indicate that some essential fatty acids, oxidized lipids, and prostaglandin $\mathrm{J}_{2}$ metabolites can bind to and activate PPAR $\gamma$ at micromolar concentrations (Kliewer et al. 1997). When PPAR $\gamma$ is bound to rosiglitazone, rosiglitazone was seen to occupy $40 \%$ of the ligand-binding pocket. Currently, there is no crystal structure of an active TR4 even though Zhou et al. (2011)

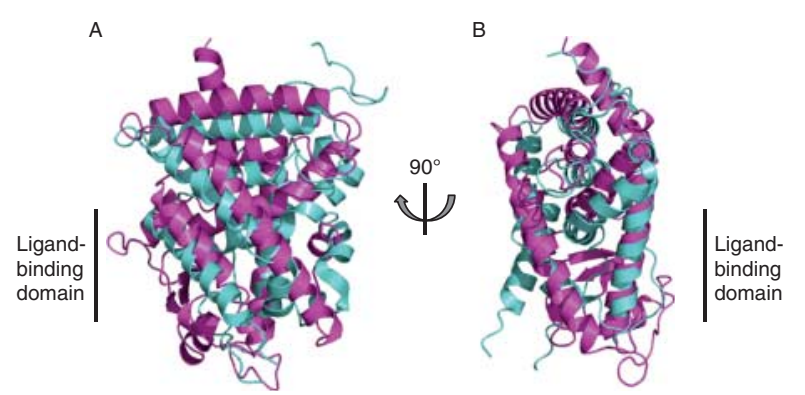

Figure 2

(A) Front view overlay of Apo PPAR $\gamma$ (pink) with Apo TR4 (cyan). (B) Side view overlay of Apo PPAR $\gamma$ (pink) with Apo TR4 (cyan). (AF2 domains were removed for a clear view of the ligand binding pockets.). have attempted to make a computational model of the active TR4 structure. TR4's ligand binding pocket was estimated to be $560 \AA^{3}$, suitable for accommodating small ligands (Zhou et al. 2011). Apart from the size of the ligand binding pocket, the shape and hydrophobic/hydrophilic nature of the pocket surface also play important roles in determining the ligand-binding specificity. PPARs have a distinct three-armed Y-shaped conformation, allowing them to bind to ligands with multiple branches or to bind to single-branched ligands such as fatty acids with multiple conformations (Xu et al. 1999). Unlike PPARs, TR4 has been suggested to be activated by retinol (vitamin A) (Zhou et al. 2011). According to the above structural analysis, due to the differences in size and shape of their ligand-binding pocket, PPARs should be regulated by a larger diversity of ligands compared with TR4. The fine molecular mechanism of why TR4 and PPAR $\gamma$ can be mediated by similar ligands is currently unknown due to a lack of more detailed structural information for TR4. Further structural characterization of the TR4 complex with a ligand would be crucial to explain the similarity between TR4 and PPAR $\gamma$ in ligand recognition.

\section{Transactivation of PPAR $\gamma$ and TR4 by receptor conformation changes via protein modulations}

\section{Phosphorylation}

Early studies concluded that phosphorylation/dephosphorylation of NRs by various kinases/phosphatases could result in conformational changes within the receptors to either induce or repress their transactivation (Jiang \& Hunter 1999). This was especially important for the study of orphan receptors, including TR4 and PPAR $\gamma$, before identification of their ligands.

Through peptide mapping and motif scan by Scansite (http://scansite.mit.edu), Kim et al. (2011) found that the serine 351 (S351) phosphorylation site, which is conserved in mouse, human, rat, and chicken TR4, is a potential target of AMPK, and applied an in vitro phosphorylation assay to prove that TR4 could be phosphorylated by AMPK in the presence of AMP. Mutation of S351 completely abolished the phosphorylation of TR4 by AMPK. Suppression of AMPK via compound C led to enhanced TR4 transactivation, whereas the activation of AMPK by AICAR resulted in suppression of TR4 transactivation. Metformin, an anti-diabetic drug, also suppressed TR4 transactivation through AMPK-mediated TR4 phosphorylation (Kim et al. 2011).

Published by Bioscientifica Ltd 
AMPK could also suppress PPAR $\gamma$ transactivation via phosphorylation of PPAR $\gamma$ in both ligand-dependent and ligand-independent mechanisms (Leff 2003), and TZDs might improve insulin sensitivity via increasing the expression and release of adiponectin, an adipokine that activates AMPK. The details of PPAR $\gamma$ phosphorylation by AMPK, however, remain unclear.

TR4 could also be phosphorylated by MAPK at its AF1 domain in the absence of specific ligands (Huq et al. 2006). MAPK activation by anisomycin causes a nearly complete loss of TR4 transactivation. In contrast, the inhibition of MAPK by PD98059 significantly increases TR4 transactivation. A mass spectrometric analysis of TR4 revealed three MAPK phosphorylation sites, Ser19, Ser55, and Ser68 in its AF1 domain. Site-directed mutagenesis studies demonstrated the functionality of phosphorylation on Ser19 and Ser68 but not Ser55. TR4 functions as a repressor when MAPK mediates the phosphorylation of the AF1 domain through the preferential recruitment of corepressor RIP140. In contrast, TR4 functions as an activator when its AF1 domain is dephosphorylated due to its selective recruitment of the coactivator PCAF (Huq et al. 2006). However, the potential physiological consequences of these MAPK phosphorylations of TR4 remain unclear. Transfection with a dominant negative MEK results in a decrease in the effects of both insulin and TZDs on PPAR $\gamma$ activity, indicating that MAPK is able to modulate PPAR $\gamma$ transactivation (Zhang et al. 1996). In vitro assays demonstrated that ERK2 and JNK were able to phosphorylate PPAR $\gamma 2$ (Adams et al. 1997). The ERK- and JNK-MAPK phosphorylation sites (Camp et al. 1999) were mapped to Ser82 of mouse PPAR $\gamma 1$ and Ser112 of mouse PPAR $\gamma 2$ (Shao et al. 1998) respectively. Substitution of this serine by alanine (S82A) leads to a loss of MAPK activator PDGFmediated repression of PPAR $\gamma$ activity (Camp \& Tafuri 1997). Phosphorylation of human PPAR $\gamma 1$ at this Ser84 results in inhibition of both its ligand-dependent and ligand-independent transactivations, and S84A mutant showed an increase in the AF-1 transactivation of PPAR $\gamma$ (Adams et al. 1997). Mutation of the MAPK Ser112 phosphorylation site in PPAR $\gamma 2$ (S112D) results in a decreased ligand-binding affinity (Shao et al. 1998). With substitution of proline by glutamine at position 115 , the human PPAR $\gamma$ becomes constitutively active through the modulation of the MAPK-dependent phosphorylation status of Ser114 (Ristow et al. 1998). Subjects carrying this mutation are extremely obese but surprisingly show a lesser insulin resistance than expected. Overall, these data indicate that prevention of $\mathrm{PPAR} \gamma$ phosphorylation may lead to an improvement of insulin sensitivity, which is similar to treatment TZDs that results in the transactivation of PPAR $\gamma$ (Rangwala et al. 2003).

The PKA activator, cholera toxin, could also increase the basal and ligand-induced activity of PPAR $\gamma$ (Lazennec et al. 2000), although details of this activation remain unclear. Treatment with PKA stimulators markedly increased PPAR $\gamma$ activity (Akahoshi et al. 2003). Interestingly, Liu et al. (2009) also found cAMP/PKA signals could induce TR4 expression by triggering $\mathrm{C} / \mathrm{EBP} \alpha$ and $\beta$ binding to the selective cAMP response elements located on the TR4 promoter that leads to the modulation of gluconeogenesis.

\section{Sumoylation}

Several laboratories recently reported that PPAR activity can be modulated by sumoylation (Ohshima et al. 2004, Yamashita et al. 2004, Pascual et al. 2005, Jennewein et al. 2008, Lai et al. 2008). Two sumoylation sites have been identified for PPAR $\gamma 2$ in mouse, lysine 107 (K107) in the AF1 domain, and lysine 395 (K395) in the AF2 domain (K77 and K365 in murine PPAR $\gamma 1$ respectively). Sumoylation of PPAR $\gamma 2$ at K107 inhibits PPAR $\gamma$-dependent gene induction, possibly by recruitment of corepressors (Ohshima et al. 2004, Yamashita et al. 2004). K107 sumoylation of PPAR $\gamma$ has no effect on its trans-repression function. In contrast, sumoylation of PPAR $\gamma 2$ at K395 leads to its recruitment to the promoters of inflammatory genes, where it represses gene transcription by preventing clearance of corepressor complexes (Pascual et al. 2005). The detailed molecular mechanism(s) behind sumoylation-mediated regulation of $\operatorname{PPAR} \gamma$ activity need to be established. It was recently discovered that FGF21 increases PPAR $\gamma$ activity by preventing its sumoylation at $\mathrm{K} 107$ while it has no effect on K395 sumoylation. FGF21 is required for the effects of rosiglitazone in WAT (Dutchak et al. 2012).

There have been no studies yet regarding the sumoylation of TR4. However, it has been shown that its close relative, TR2, can be sumoylated, resulting in the replacement of coregulators recruited to the regulatory region of its endogenous target gene Oct4 (Pou5f1). Unsumoylated TR2 can activate Pou $5 f 1$ to enhance embryonic carcinoma cell proliferation and is localized on the promyelocytic leukemia (PML) nuclear bodies. Increased expression of TR2 may lead to more sumoylation at K238 that may result in release from the nuclear bodies to act as a repressor. Sumoylation of TR2 also induces an exchange of its corepressor RIP140 with the coactivator PCAF, which can then switch TR2 from an activator to a repressor. This involves dynamic

Published by Bioscientifica Ltd. 
partitioning of TR2 into Pml-containing and Pml-free pools (Park et al. 2007, Gupta et al. 2008).

\section{Acetylation}

TR4 can be acetylated at K175 and K176, which attenuates its DNA binding ability to TR4 response elements (TR4REs) on its target genes (Xie et al. 2011). The coregulator ARA55 increased TR4 acetylation levels via modulation of HAT enzymes bound to the ARA55-TR4 complex. However, the physiological function of acetylated TR4 remains unclear (Xie et al. 2011).

Few results regarding acetylation of PPAR $\gamma$ have been reported. However, COUP-TFII may be able to recruit the SMRT corepressor complex to the first intron of both PPAR $\gamma 1$ and PPAR $\gamma 2$ and maintains the local chromatin in a hypoacetylated state, which may lead to the suppression of adipogenesis (Okamura et al. 2009).

\section{Ubiquitination}

The PPAR $\gamma$ protein has a short half-life $\left(t^{1} / 2<4 \mathrm{~h}\right)$ in adipocytes (Waite et al. 2001). Certain PPAR $\gamma$ ligands stimulate a reduction in $\operatorname{PPAR} \gamma$ protein level, and the ligand-dependent degradation of PPAR $\gamma$ by the proteasome is regulated by polyubiquitination (Hauser et al. 2000). The AF2 domain of PPAR $\gamma$ is important for ligand-induced downregulation (Hauser et al. 2000). Interferon- $\gamma$ also promotes the ubiquitination and degradation of PPAR $\gamma$ in fat cells (Floyd \& Stephens 2002). Interestingly, a recent finding indicates that PPAR $\gamma$ itself can act as an E3 ubiquitin ligase and induce $\mathrm{NF} \kappa \mathrm{B} / \mathrm{p} 65$ ubiquitination and degradation (Hou et al. 2012), although no evidence indicates that PPAR $\gamma$ regulates the ubiquitination by itself. To date, there are no reports of ubiquitination studies on either TR4 or TR2.

\section{Signaling pathways of TR4 vs PPAR $\gamma$}

\section{Signaling pathways via downstream target genes with conserved DNA response elements}

As TR4 and PPAR $\gamma$ share some homology in their DBD and they both can be activated by similar ligands/activators, one might expect that they may also modulate similar downstream target genes via binding to the similar DNA response elements existing in the promoter region of their target genes. TR4 binds to TR4REs, which consist of an imperfect direct repeat (DR) of two consensus sequences, AGGTCA, separated by 0-5 spacing nucleotides (Lee et al. 2002). Of the DR sequences recognized by TR4, DR-1, has the highest affinity for TR4 (Kim et al. 2003). In contrast to the broad range of TR4REs with various spacing nucleotides, and PPAR $\gamma$ binding sites, PPREs, are generally DRs with one intervening nucleotide (DR-1). Tables 2 and 3 summarize and compare the TR4REs and PPREs that were found in identified target genes.

Although TR4 and PPAR $\gamma$ recognize similar DNA sequences and modulate many similar target genes, there are also distinct target genes that so far are only regulated by either TR4 or PPAR $\gamma$. For example, SV40 has been

Table 2 The target genes and binding sites of TR4 and PPAR $\gamma$

\begin{tabular}{l} 
Target genes \\
\hline PEPCK \\
GATA1 \\
CRBPII \\
Apolipoprotein E (ApoE) \\
HBV \\
CNTFR \\
NDUFAF1 \\
SV40 \\
Rat P450cc24 \\
Rat $\alpha$-MHC \\
Oxytocin \\
S14 \\
RAR $\beta$ \\
CD36 \\
HIV-LTR \\
SCD1 \\
FATP1 \\
Steroid 21-hydroxylase \\
Rev-Erb $\alpha$ \\
LXR $\alpha$ \\
\end{tabular}

\begin{tabular}{l} 
TR4 binding sites \\
\hline DR1 $(-439 /-451)$ \\
DR1 \\
DR1 \\
DR1 (-319) \\
DR1 \\
DR1 \\
DR0, DR2, DR5 \\
DR2 \\
DR3 \\
DR4 \\
DR0, DR4 \\
DR4 \\
DR5 \\
DR1 \\
DR9 or half site \\
DR0 \\
DR1 \\
Half site
\end{tabular}

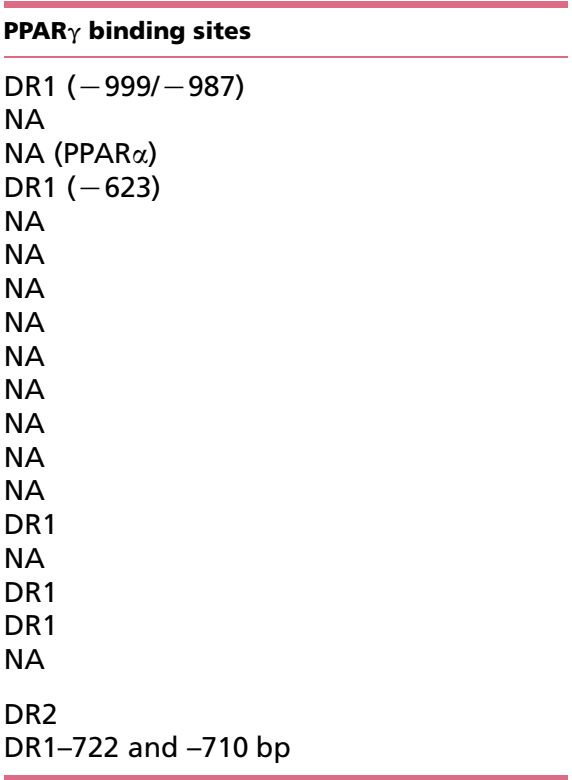


Table 3 Nuclear receptors TR4 and PPAR $\gamma$ are fatty acid sensors via modulation of similar/distinct target genes

\begin{tabular}{l} 
Tissues \\
\hline Adipose \\
Pancreas \\
Muscle \\
Macrophage \\
Kidney \\
Vascular smooth muscle cell
\end{tabular}

PPAR target genes

$\uparrow$ Adiponectin, FABP, FATP1, CD36, PEPCK, glycerol kinase

$\downarrow P A / 1$, resistin, IL6, TNF $\alpha$, leptin, $11 \beta-H S D 1$

$\uparrow L P L$, acyl-coA synthase, $\beta 3-A R$

$\uparrow \mathrm{C}-\mathrm{Cb}$ associating protein, GLUT4, PI3K, IRS1, IRS2

$\downarrow P E P C K(\uparrow P E P C K$ in adipose tissue)

$\uparrow S C D 1$

$\uparrow$ GLUT2, liver type glucokinase (LGK)

$\uparrow$ GLUT2, GLUT4

$\uparrow$ GLUT2, GLUT4, adiponectin, PI3K, $\downarrow P D K 4$

$\downarrow U C P 3$

$\uparrow C D 36$

$\uparrow L X R \alpha, A B C A 1$

$\downarrow$ iNOS, IL6, TNF $\alpha, M C P 1, I L 12$, IFN $\gamma$

$\uparrow \mathrm{Na}^{+}$channel

$\uparrow \mathrm{p} 27^{\mathrm{Kip} 1}$ and RB

$\uparrow A M P K$ activity

\section{TR4 target genes}

NA

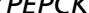

$\uparrow S C D-1$

NA

Ndufaf1

$\uparrow C D 36$

NA

NA identified as a TR4 target gene (Lee et al. 1995), but not a PPAR $\gamma$ target gene. It is not completely clear whether these two receptors compete for DNA binding, or whether they complement each other in different tissues, at different developmental time points. However, mouse embryos lacking PPAR $\gamma$ are not viable by embryonic day 11 (E11) as a result of severe trophoblast dysmorphogenesis (Barak et al. 1999), and mice lacking TR4 also have serious development defects (Collins et al. 2004). Based on the phenotypes of $T R 4^{-/-}$and PPAR $\gamma$ knockout mice $\left(P P A R \gamma^{-1-}\right)$, TR4 and PPAR $\gamma$ seem to have unique properties that are essential for the viability of the organisms.

\section{Signaling pathways via modulation of interacting coregulators}

Coregulators are NR-interacting proteins that modulate the NR function. The downstream signaling pathways of both PPAR $\gamma$ and TR4 are subject to regulation by their coregulators (see details in Table 4).

NRs as interacting coregulators for TR4 vs PPAR $\gamma \quad T R 4$ is a unique NR with the capacity to form heterodimers with various other NRs to modulate its transactivation. TR4 forms heterodimers preferentially with TR2 in solution as well as on TR4RE containing DR5. The three leucine residues on helix 10 of TR2 are critical for this dimerization (Lee et al. 1998). Coexpression of TR4 and TR2 resulted in a much stronger repression of a DR5containing reporter than expression of either receptor alone. In the developing testis, TR4 and TR2 are expressed in the same cell populations and exhibit a parallel expression pattern during development (Lee et al. 1998).
TR4 interacts with $\mathrm{AR}$, and this heterodimerization prevents TR4 from binding to its target DNA and thus suppresses expression of TR4 target genes. Interestingly, expression of AR target genes was also repressed by the dimerization with TR4 (Lee et al. 1999). ARA55 is one of the coregulators that AR and TR4 share (Xie et al. 2011). ARA55 enhances AR transcriptional activity but inhibits TR4 activity. We also found that inactivation of ARA55 inhibits the agonist effect of antiandrogens in prostate cancer (PCa) cells (Rahman et al. 2003). Does increased TR4 activity induced by ARA55 inactivation play a role here? Further experiments are needed to answer this question. To date, no evidence indicates that PPAR $\gamma$ directly binds to AR. However, it has been found that testosterone inhibits the activity of PPAR $\gamma$ (Du et al. 2009) and troglitazone suppresses AR in a PPAR $\gamma$-independent manner (Yang et al. 2007). TR4 can also repress ER-mediated transactivation through direct protein-protein interaction. The interaction between TR4 and ER would suppress the homodimerization of ER and prevent ER from binding to the estrogen response element that results in the suppression of ER target genes and ER-mediated cell proliferation in MCF-7 cells (Shyr et al. 2002). A physical interaction between PPAR $\gamma$ and $\mathrm{ER} \alpha$ was also observed in MCF-7 cells (Bonofiglio et al. 2005). Treatment with $17 \beta$-estradiol or a PPAR $\gamma$ agonist, BRL49653, decreased this interaction slightly, whereas an ER inhibitor, ICI182780, strongly inhibited the association. It is still not very clear how this interaction affects the activity of the two receptors. Houston et al. (2003) found that in leiomyoma cells, the stimulation of PPAR $\gamma$ signaling inhibited ER-mediated cell growth and gene expression. On the other hand, $17 \beta$-estradiol suppressed

Published by Bioscientifica Ltd. 
Table 4 PPAR $\gamma$ and TR4-associated proteins

\begin{tabular}{l} 
Associated protein \\
\hline RIP140 \\
AR \\
TIP27 \\
TRA16 \\
ER \\
CBP/p300 \\
HDAC \\
ARA55 \\
TR2 \\
HNF4 $\alpha$ \\
\\
ARA70 \\
SRC-1,2,3 \\
PGC-1 \\
PRIC285 \\
PBP \\
PRIP \\
BAF60 \\
TRAP220 \\
NCOR \\
SMRT \\
Sirt1 \\
\hline
\end{tabular}

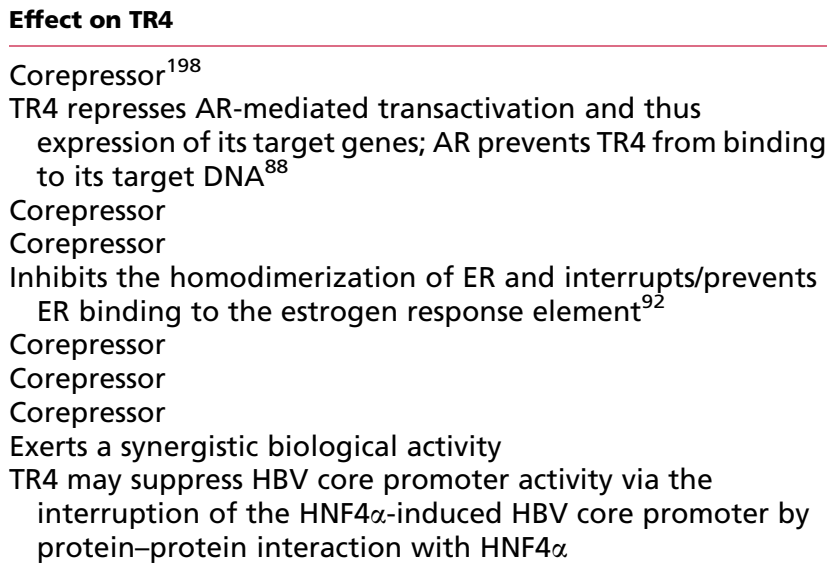
interruption of the HNF4 $\alpha$-induced HBV core promoter by protein-protein interaction with HNF4 $\alpha$

Coactivator

Coactivator

Coactivator

Coactivator

Coactivator

Coactivator

Coactivator

Coactivator

Corepressor

Corepressor

Corepressor
PPAR $\gamma$-induced adipogenesis and adipocyte-specific gene expression through both $\mathrm{ER} \alpha$ and $\mathrm{ER} \beta$ (Foryst-Ludwig et al. 2008, Jeong \& Yoon 2011).

TR4 also functions as a transcriptional suppressor via competing for the same hormone response elements (HREs) that are bound by other NRs, such as RAR/RXR and VDR/RXR. Interestingly, TR4 can also interact with T3R and consequently promoted ligand-induced thyroid hormone receptor $\alpha$-mediated transcriptional activity and expression of its downstream target genes and cellular functions (Huang et al. 2010).

$\operatorname{PPAR} \gamma$ can form a heterodimer with $\mathrm{RXR} \alpha$ to bind to promoters of downstream target genes (Kliewer et al. 1992). The heterodimerization with RXR is required for PPAR $\gamma$ DNA binding (Tan et al. 2005). As RXR is a common heterodimeric binding partner for several NRs, PPAR $\gamma$ usually needs to compete with other NRs, including VDR (Wood 2008) or thyroid hormone receptor $\alpha$ (Wang et al. 2005), for a limited amount of the RXR.

A sequence alignment of PPAR $\gamma$ and TR4 revealed a key amino acid $\Sigma$ residue in the PPAR $\gamma$ heterodimerization motif and this amino acid was changed to an alanine in the TR4 motif (Fig. 3). This $\Sigma$ residue (E or D) is crucial for forming a salt-bridge with R393 in helix 9 of RXR; thus, this amino acid difference might, in part, explain the lack of interaction between TR4 and RXR. Structurally, PPAR $\gamma$ and TR4 are restricted to form different dimers, thus resulting in different signaling pathways. There has also been a report that PPAR $\gamma$ can physically interact with the glucocorticoid receptor (GR; Nie et al. 2005), and this interaction resulted in the inhibition of histone $\mathrm{H} 4$ acetylation and p65 binding to the eotaxin promoter and the suppression of eotaxin gene transcription. More interestingly, there was a recent report that claimed that TZDs are partial agonists for the GR (Matthews et al. 2009), that can induce GR phosphorylation (Ser211), which was once believed to be a GR ligand-binding-specific effect in both PPAR $\gamma$-expressing and PPAR $\gamma$-null cells.

Coactivators as interacting coregulators for PPAR $\gamma$ and TR4 Steroid receptor coactivator (SRC-1) was identified as a PPAR $\gamma$ coactivator that can enhance ligand-induced PPAR $\gamma$ transactivation (Zhu et al. 1996, Nolte et al. 1998). PPAR $\gamma$ can also interact with members of the SRC family such as SRC-2 and/or SRC-3 to enhance its transactivation, which results in positive effects on fat storage (Hartig et al. 2011). The absence of SRC-3 may abolish adipocyte differentiation by altering PPAR $\gamma$ mediated transactivation of genes that are important for lipid storage (Picard et al. 2002). Indeed, in SRC-3 ${ }^{-/-}$

Published by Bioscientifica Ltd. 


$\begin{array}{llllllllllllllllllllll}\text { PPAR } & 459 & \mathrm{~L} & \mathrm{~F} & \mathrm{~A} & \mathrm{~K} & \mathrm{~L} & \mathrm{~L} & \mathrm{Q} & \mathrm{K} & \mathrm{M} & \mathrm{T} & \mathrm{D} \\ \mathrm{TR} 4 & 539 & \mathrm{R} & \mathrm{L} & \mathrm{A} & \mathrm{R} & \mathrm{I} & \mathrm{L} & \mathrm{V} & \mathrm{R} & \mathrm{L} & \mathrm{P} & \mathrm{Q} & \mathrm{I} & \mathrm{V} & \mathrm{T} & & 475 \\ \mathrm{~A} & \mathrm{~L} & \mathrm{R} & \mathrm{L} & \mathrm{M} & \mathrm{S} & \mathrm{S} & \mathrm{N} & 556\end{array}$

Figure 3

Sequence alignment of PPAR $\gamma$ with TR4 at heterodimerization motif in N-terminal of helix 10. Arrow indicates the position of the $\Sigma$ substitution.

mouse embryonic fibroblasts (MEFs), adipocyte differentiation was severely impaired, and re-expression of SRC-3 was able to restore the ability of MEFs to differentiate into adipocytes. At the molecular level, SRC-3 acts synergistically with the transcription factor CAAT/enhancer-binding protein to control the gene expression of PPAR $\gamma 2$.

Subunit 1 of the mediator complex (named Med1 or PBP), which represents a large complex of coactivators, plays an important role in adipocyte differentiation by coactivating PPAR $\gamma$ (Misra et al. 2002). PPAR $\gamma$-interacting protein (PRIP) also acts as a molecular scaffold that cooperatively enhances PPAR $\gamma /$ RXR-mediated transactivation that results in positive regulation of adipogenesis via binding to the aP2 promoter in adipocytes (Qi et al. 2003).

PGC-1 is an unusual coactivator among known NR coactivators in that its expression is dramatically regulated with respect to both tissue selectivity and the physiological state of the animal (Feige \& Auwerx 2007). PGC-1 is also distinct from the known coactivators in that it appears to use different sequence motifs for proteinprotein docking, on both sides of the receptor-coactivator pair. Nearly all the known coactivators and corepressors utilize LXXLL sequences to bind to the ligand-regulated helix 12 in the carboxy terminal AF- 2 domain. In contrast, PGC-1 utilizes a domain rich in proline residues to bind to a region that overlaps the DNA-binding and hinge region of PPAR $\gamma$ (Puigserver et al. 1998). There had been few identified coactivators for TR4 until Huq et al. (2006) identified a classic steroid receptor family coactivator, p300/CREB-binding protein-associated factor (PCAF). Although originally characterized as a histone acetyltransferase, PCAF also acetylates non-histone transcriptionrelated proteins like p53 (Schiltz \& Nakatani 2000). TR4 activity is positively regulated by PCAF through an unknown mechanism. Both WT full-length TR4 and TR4 LBD deletion mutant proteins were found to interact strongly with PCAF, indicating that the LBD of TR4 is not required for the interaction (Huq et al. 2006). Interestingly, the authors also found that the hyperphosphorylated TR4 preferentially recruited corepressors while the hypophosphorylated TR4 recruited coactivators (Huq et al. 2006).

Corepressors as interacting coregulators for PPAR $\gamma$ and TR4 Formation of the corepressor complex including PPAR $\gamma$ with NCoR and SMRT may result in suppression of transactivation of the PPAR $\gamma$-mediated deacetylase Sirt1, which may then lead to reduced loss of fat via suppression of lipolysis with a limitation of fatty acid mobilization (Guan et al. 2005). Addition of siRNA for NCoR and SMRT may also result in enhanced adipogenesis via increased PPAR $\gamma$-mediated pro-adipogenic target gene expression. PPAR $\gamma$ can recruit SMRT and NCoR in the absence of ligands to modulate PPAR $\gamma$-mediated transcriptional activity (Yu et al. 2005).

The PDZ-binding motif (Miglio et al. 2009) is another ligand-independent PPAR $\gamma$ corepressor that inhibits adipogenesis (Debril et al. 2005). The scaffold attachment factor B1 (SAF-B1) and unphosphorylated RB also function as PPAR $\gamma$ corepressors involved in regulation of adipogenesis (Debril et al. 2005). The unphosphorylated RB can inhibit the clonal expansion phase of adipocyte differentiation by recruiting histone deacetylase 3 .

The tribbles homolog 3 (TRB3), containing a single kinase domain without enzymatic activity, downregulates PPAR $\gamma$ transcriptional activities by protein-protein interaction (Takahashi et al. 2008). TRB3 gene and protein expression was increased during adipocyte differentiation concomitantly with an increase in the mRNA levels of CCAAT/enhancer binding protein homologous protein. Forced TRB3 expression in 3T3-L1 cells decreased the mRNA levels of PPAR $\gamma$-target genes and intracellular triglyceride (TG) levels and TRB3 could also inhibit PPAR $\gamma$-dependent adipocyte differentiation in PPAR $\gamma$ expressing 3T3-L1 cells (Takahashi et al. 2008).

TIP27 has two zinc finger motifs and can function as a TR4 corepressor. TIP27 interacts with TR4 through the region spanning Asp39 and Lys79, leading to suppression of TR4-mediated DR1 transactivation. This repression does not involve the inhibition of TR4 homodimerization or

Published by Bioscientifica Ltd. 
DR1 binding but may be due to an interruption of interaction between TR4 and its coactivators (Nakajima et al. 2004).

TR4-associated protein (TRA16) is a selective TR4 corepressor with little influence on the transactivation of AR or GR. TRA16 may suppress TR4-mediated transactivation via decreasing TR4 binding to the TR4REs on the target gene(s). TRA16 can also block the interaction between TR4-DBD and TR4-LBD (Yang et al. 2003). These unique suppression mechanisms indicate that TRA16 may function as a novel corepressor to selectively suppress TR4-mediated transactivation.

\section{The pathophysiological functions of PPAR $\gamma$ and TR4}

\section{Metabolic diseases}

The first striking finding revealing the opposing functions of these two receptors comes from studies on their modulation of insulin sensitivity: loss of PPAR $\gamma$ reduced insulin sensitivity (Kubota et al. 1999); in contrast, loss of TR4 increased insulin sensitivity (Kim et al. 2011).

The development of insulin resistance is an early event in the onset and progression of type 2 diabetes mellitus (T2DM) and PPAR $\gamma$ ligand TZDs have been used in T2DM as insulin sensitizers with adipose tissue as the primary target tissue where PPAR $\gamma$ is predominantly expressed. The functional mechanism of TZDs as insulin sensitizers includes the following: i) they can selectively stimulate lipogenic activities in fat cells resulting in greater insulin suppression of lipolysis (Oakes et al. 2001), thus decreasing infiltration of free fatty acids (FFAs) into other tissues leading to the insulin-desensitizing effects of FFAs in muscle and liver (Granberry et al. 2007). ii) TZDs can alter the expression and release of adipokines, such as resistin and TNF- $\alpha$, that results in alteration of insulin sensitivity (Steppan et al. 2001). Conversely, the level of adiponectin is increased after treatment with TZDs (Maeda et al. 2001). iii) TZDs can enhance the lipid storage capacity of adipose tissue by increasing the number of small adipocytes. This lipogenic effect may lead to a reduction of deleterious lipid accumulation in other insulin-sensitive tissues such as the muscle and liver, thus reducing insulin resistance (Okuno et al. 1998). Since PPAR $\gamma$ may function as a key factor for adipogenesis and a critical determinant of body fat distribution (Tsai \& Maeda 2005), T2DM patients treated with TZDs may develop an accumulation of subcutaneous fat with reduced or unchanged visceral adipose tissue volume. This is a positive effect because subcutaneous adipose tissue is metabolically less harmful than visceral adipose tissue despite their tendency to induce weight gain (Bays et al. 2004). In summary, TZDs can ameliorate insulin resistance due to lipotoxicity in obesity- and lipodystrophyassociated T2DM (Unger \& Orci 2001). In contrast, $T R 4^{-/-}$mice have reduced fat mass and smaller adipocytes. $T R 4^{-/-}$mice display low glucose levels at birth and under fasting conditions have improved insulin sensitivity, indicating that TR4 is an important modulator of insulin sensitivity and glucose/lipid metabolism. TR4 also controls liver glucose metabolism through transcriptional regulation of phosphoenolpyruvate carboxykinase (PEPCK) (Liu et al. 2007), the key enzyme in gluconeogenesis (Postic et al. 2004). PEPCK expression is reduced in TR4 $4^{-/}$mice, and the hypoglycemia at birth and under fasting conditions in $T R 4^{-/-}$mice is caused by failure to induce PEPCK expression.

In addition to glucose metabolism, TR4 also plays an important role in lipid metabolism by directly regulating the expression of stearoyl-CoA desaturase 1 (SCD-1) (Kim et al. 2011), which is the rate-limiting enzyme in the biosynthesis of monounsaturated fatty acids. SCD-1 activity has been implicated in obesity, diabetes, lipogenesis, $\beta$-oxidation, and insulin sensitivity (Cohen et al. 2003, Cohen \& Friedman 2004). TR $4^{-/-}$mice showed reduced fat volume and TG deposition and improved insulin sensitivity that may be partially due to reduced SCD-1 expression. Moreover, TR4 controls fatty acid uptake through transcriptional regulation of fatty acid transport protein 1 (FATP1) in 3T3-L1 adipocytes (Choi et al. 2011).

More questions remain to be answered; for instance, how the newly identified TR4 upstream modulators, such as TZDs, could affect PEPCK and SCD-1 expression, thus altering systemic lipid and glucose metabolism as well as insulin sensitivity.

\section{Cardiovascular diseases}

The second striking finding is that $\operatorname{PPAR} \gamma$ attenuates atherosclerosis (Francis et al. 2003) but TR4 might increase the risk of atherosclerosis (Xie et al. 2009) in animal models.

Atherosclerosis is a vascular disease that arises from an imbalance in lipid metabolism and a chronic immune response driven by the accumulation of cholesterol-laden macrophages in the artery wall (Moore et al. 2013). It is the usual cause of heart attacks, strokes, and other cardiovascular diseases. Decreases in atherosclerosis lesions were seen in mouse models after treatment with TZDs (Li et al. 2000). TZDs also reduced inflammatory cytokine production by macrophages (Jiang et al. 1998) and inhibited

Published by Bioscientifica Ltd. 
monocyte chemotactic protein-1-directed migration of monocytes (Kintscher et al. 2000). PPAR $\gamma$ has been shown to regulate transcription of key genes in different cell types at different stages of the development and progression of atherosclerosis. PPAR $\gamma$ is prominently expressed in activated monocytes/macrophages, including foam cells in atherosclerotic lesions (Neve et al. 2000), which promotes monocyte differentiation and cholesterol efflux in macrophages through upregulation of ABCA1, ABCG1, and apoE (Tontonoz et al. 1998, Chawla et al. 2001). Activation of PPAR $\gamma$ by its ligands (Nicholson \& Hajjar 2004) increased the expression of CD36, a class B scavenger receptor implicated in oxLDL uptake. CD36 is not the only scavenger receptor that is influenced by PPAR $\gamma$. The expression of scavenger receptor class A (SRA) (Misra et al. 2002), utilized in the uptake of modified lipids, is also suppressed by PPAR $\gamma$ (Ahmed et al. 2009). In fact, the in vivo data with either LDL receptor (LDLR) or apoE knockout mice indicate that cholesterol accumulation in macrophages might be prevented by PPAR $\gamma$ activation induced by TZDs (Moore et al. 2001). In addition to macrophages, endothelial cells and smooth muscle cells (SMC) also participate in the development of atherosclerosis by mediating immune cell recruitment and vascular remodeling. PPAR $\gamma$ regulates the function of both these cell types during the development of atherosclerosis.

SMC-specific PPAR $\gamma$ deficiency increased atherosclerosis in male mice. The TZD, pioglitazone, suppresses Ang II-induced atherosclerosis lesions, but the effect is lost in mice with SMC-specific PPAR $\gamma$ deficiency (Subramanian et al. 2010). Furthermore, PPAR $\gamma$ activation ameliorated endothelial cell activation and reduced the following adherence of monocytes to the activated endothelial cells probably through suppressing the diacylglycerol-PKC pathway (Verrier et al. 2004) and inhibiting the expression of vascular cell adhesion molecule (VCAM-1) and intercellular adhesion molecule (ICAM-1) (Dolezalova et al. 2007). Interestingly, recent studies found that CD36 is also a TR4 target gene and thus TR4 might have direct and indirect influences on atherogenesis via regulation of CD36

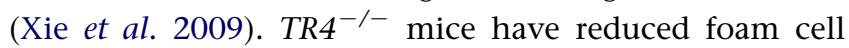
formation with reduced CD36 gene expression and TR4 could function as a transcriptional factor to directly regulate $C D 36$ gene expression in macrophage cells. Overexpression of CD36 can rescue impaired foam cell formation in macrophages due to reduced expression of TR4, indicating that CD36 is involved in TR4-mediated foam cell formation (Xie et al. 2009). In vitro studies showed that TZDs could activate the CD36 promoter through TR4 via binding to the same response element as $\operatorname{PPAR} \gamma$.
These results indicated that TZDs might modulate atherosclerosis via activation of two different NRs, TR4, and PPAR $\gamma$, which might lead to differential outcomes in atherosclerosis. Revealing detailed mechanisms by which these two NRs respond to TZDs in mediating lipid metabolism will be beneficial to our understanding of the complexity of the activity and specificity of TZDs.

\section{Cancer}

The third striking finding is the differential influences of these two NRs on the progression of PCa. PPAR $\gamma$ was believed to act as a tumor suppressor in tumors of prostate, breast and colon by inducing apoptosis (Koeffler 2003, Philips et al. 2004, Kim et al. 2007). Yet TR4's roles in PCa progression can be either as an enhancer of PCa metastasis or as an suppressor of PCa development.

$\operatorname{PPAR} \gamma$-mediated apoptosis and cell differentiation have been found to be beneficial in the chemotherapy of different types of cancers including prostate, breast, and colon (Koeffler 2003, Philips et al. 2004, Kim et al. 2007). Moderate anticancer activities of PPAR $\gamma$ ligands with minimal toxicities have been observed in patients with liposarcomas and PCa, possibly due to decreased expression of cyclin D1 and increased expression of p21waf1 (Wang et al. 2001, Wei et al. 2008, Lyles et al. 2009). In particular, troglitazonetreated patients showed significant induction of terminal adipocyte differentiation and reduction in Ki-67 biological marker levels for cell proliferation (Demetri et al. 1999). Surprisingly, some or many of these effects may occur independently of PPAR $\gamma$, which may raise the interesting question of whether the TZDs may also modulate tumor growth via a different NR, such as TR4.

TR4 acts as a caretaker tumor suppressor that suppresses PCa initiation through promoting DNA repair and maintaining genome integrity. $T R 4^{-/-}$mice developed prostatic intraepithelial neoplasia (PIN) yet their WT littermates showed normal prostate histology. PTEN ${ }^{+/-} / T_{R} 4^{+/-}$mice and not $P_{T E N}^{+/-} / T_{R} 4^{+/+}$mice developed PIN and formed PCa tumors at 15 months (Lin et al. 2014). Interestingly, a survey of PCa samples also found that one allele of the TR4 gene is deleted in 9\% of PCa patients (SJ Lin, CY Lin, K Izumi, E Yan, X Niu, DR Yang, N Wang, Li G and $\mathrm{C}$ Chang, unpublished observations). These results indicate that TR4 is a tumor suppressor gene in the early development of PCa (Lin et al. 2014). However, in vitro migration/invasion assays and in vivo mouse studies also found that TR4 promoted migration/invasion of various PCa cells via modulation of CCL2/CCR2 axis, indicating that TR4 can enhance PCa metastasis (XF Ding,

Published by Bioscientifica Ltd.

Downloaded from Bioscientifica.com at $04 / 26 / 2023$ ๑6:13: ๑๑AM via free access 
DR Yang, SO Lee, YL Chen, LQ Xia, SJ Lin, SC Yu, YJ Niu, GH Li and C Chang, unpublished observations).

Importantly, Lin and colleagues (SJ Lin, DR Yang, $\mathrm{N}$ Wang, M Jiang, H Miyamoto, G Li and C Chang, unpublished observations) found that knocking down TR4 suppressed cell proliferation and overexpression of TR4 promoted cell proliferation in PPAR $\gamma$-knocked-out $\left(\mathrm{mPrE}^{-/-}\right)$cells. In contrast, they also found that knocking down TR4 promoted cell proliferation and overexpression of TR4 suppressed cell proliferation in PPAR $\gamma$-naïve $\left(\mathrm{mPrE}^{+/+}\right)$cells (Lin et al. 2014). Similar results were also obtained showing that knocking down TR4 significantly suppressed $\mathrm{PCa}$ tumorigenesis in $\mathrm{mPrE}^{-1-}$ cells. In contrast, overexpression of TR4 promoted prostate tumorigenesis in $\mathrm{mPrE}^{-1-}$ cells (SJ Lin, DR Yang, N Wang, M Jiang, H Miyamoto, G Li and C Chang, unpublished observations). Results of experiments using a xenografted PCa mouse model also demonstrated that knocking down TR4 or overexpression of TR4 in mice with xenografted PCa $\mathrm{mPrE}^{-1-}$ cells might lead to altered PCa progression (SJ Lin, DR Yang, N Wang, M Jiang, H Miyamoto, G Li and $\mathrm{C}$ Chang, unpublished observations). Together, these results indicated that the existence of PPAR $\gamma$ might influence the effects of TR4 on PCa progression.

Lin and colleagues tested whether the existence of TR4 might also affect PPAR $\gamma$ influences on prostate cancer progression, and found that rosiglitazone could promote CWR22Rv1 cell growth significantly after TR4 was knocked down using silenced TR4 (CWR22Rv1-siTR4). In contrast, rosiglitazone showed little effect on control CWR22Rv1 cell growth compared with control scrambled TR4 (CWR22Rv1scr) (SJ Lin, CY Lin, K Izumi, E Yan, X Niu, DR Yang, N Wang, Li G and C Chang, unpublished observations). They also confirmed these differential in vitro phenotypes using another PCa cell line, C4-2. Similar results were also obtained when they applied a colony formation assay in both PCa CWR22Rv1 and C4-2 cells (SJ Lin, CY Lin, K Izumi, E Yan, X Niu, DR Yang, N Wang, Li G and C Chang, unpublished observations). Importantly, results from a xenografted PCa mouse model using rosiglitazone-treated CWR22rv1-scr and CWR22rv1-siTR4 cells also showed that mice with CWR22Rv1-siTR4 xenografts had bigger tumors and more metastases than mice with CWR22Rv1-scr xenografts. Together, these results indicated that rosiglitazone has adverse effects on PCa progression in vitro and in vivo when TR4 is knocked down, which might indicate that the effects of rosiglitazone on PCa progression might vary and might be dependent on the status of the TR4 expression in PCa (SJ Lin, CY Lin, K Izumi, E Yan, X Niu, DR Yang, $\mathrm{N}$ Wang, Li G and C Chang, unpublished observations).

\section{Other diseases including neurological diseases, aging, mitochondrial diseases, and reproduction}

Neurological diseases $\operatorname{PPAR} \gamma$ has positive roles in neuroprotection and neurological improvement following ischemic injury (Uryu et al. 2002) and TR4 promotes nervous system development (Chen et al. 2005, Zhang et al. 2007).

TR4 shows the highest expression in the CNS among all tissues and the expression of TR4 correlates with the process of neurogenesis, indicating a role for TR4 in the nervous system during development.

$T R 4^{-/-}$mice exhibited behavioral deficits in motor coordination starting during the postnatal stages. Analysis of the postnatal and adult $\mathrm{TR} 4^{-1-}$ mice cerebellum revealed gross abnormalities in foliation. $T R 4^{-/-}$mice cerebellar cortex shows decreased lamination, including reduction in the thickness of both the molecular layer (Pascual et al. 2005) and the internal granule layer (IGL) (Chen et al. 2005). This may be caused by disrupted granule cell proliferation within the external granule cell layer (Hankey et al. 1999), delayed inward migration of post-mitotic granule cells, and increased apoptosis during cerebellar development (Chen et al. 2005). In addition, development of Purkinje cells was abnormal in the postnatal $T R 4^{-/-}$mice cerebellum, as indicated by aberrant dendritic arborization (Chen et al. 2005, 2007).

In addition to the abnormal cerebellum development, myelination was reduced significantly in $T R 4^{-/-}$mice forebrains and the differentiation of glial cells, in particular oligodendrocytes, was abnormal in TR4 $4^{-/-}$ mice in early developmental stages (Zhang et al. 2007), indicating that TR4 is required for proper myelination in the CNS and is particularly important for oligodendrocyte differentiation and maturation in the forebrain regions. Further analysis reveals that CC-1-positive $\left(\mathrm{CC}-1^{+}\right)$oligodendrocytes are decreased in $\mathrm{TR}^{-/-}$mice forebrains (Zhang et al. 2007). Mechanical dissection revealed higher Jagged1 expression levels in axon-fiber-enriched regions in $T R 4^{-/-}$mice forebrains, suggesting a more active Notch signaling in these regions that correlates with previous reports showing that Notch activation inhibits oligodendrocyte differentiation (Zhang et al. 2007).

PPAR $\gamma$ agonists can prevent neuronal death resulting from $N$-methyl-D-aspartate (NMDA) excitotoxicity in brain in vitro or in vivo (Zhao et al. 2006). Bordet et al. (2006) believed that PPAR activation induces a decrease in neuronal death by preventing inflammation and oxidative damage implicated in cerebral injury. PPAR $\gamma$ agonists also inhibit macrophage and microglial activation, which

Published by Bioscientifica Ltd 
contributes to degenerative, ischemic, or inflammatory processes that eventually lead to neuronal death (Kielian $\&$ Drew 2003). PPAR $\gamma$ agonists are also able to inhibit the entry of inflammatory cells into the CNS from the periphery by inhibition of chemokines, adhesion molecules, and metalloproteinases (Kielian \& Drew 2003). Administration of the PPAR $\gamma$ agonists, troglitazone or pioglitazone, dramatically reduced infarction volume and improved neurological function following transient middle cerebral artery occlusion in rats.

Aging PPAR $\gamma$ itself is not yet directly linked to aging, but as it improves insulin resistance, hyperlipidemia and glycemic levels (Lee et al. 2003), very often the results of aging, it in turn may help to increase longevity. Loss of TR4 leads to retarded development and aging (Lee et al. 2011).

Aging is commonly associated with metabolic syndromes and because the activation of PPAR $\gamma$ by TZDs improves insulin resistance, hyperlipidemia, and glycemic levels, it constitutes an important part of therapy for metabolic syndromes. This therapy might help to increase longevity, even though it may not directly affect the process of biological aging. Additionally, aging is commonly associated with low-grade chronic inflammation. As PPAR $\gamma$ has long been known to be an anti-inflammatory molecule that suppresses NF- $\mathrm{BB}, \mathrm{AP}-1$, and STAT and decreases production of cytokines and chemokines, this effect of PPAR $\gamma$ may be an added benefit increasing longevity (Zhang \& Zheng 2008). PPAR $\gamma$ can also increase klotho mRNA and protein expression (Zhang et al. 2008), an important protein involved in aging (Kurosu et al. 2005). All these data indicate that PPAR $\gamma$ is a key factor influencing aging.

$T R 4^{-1-}$ mice exhibited an early onset of premature aging phenotypes that are associated with increased oxidative stress and genome instability (Lee et al. 2011). At the cellular level, a rapid cellular growth arrest accompanied by elevated intracellular reactive oxygen species (ROS) and more DNA damage were observed in TR4 ${ }^{-/-}$MEFs. Restoring TR4 to TR4 ${ }^{-1-}$ MEFs reduced ROS levels and single-strand DNA breaks, which lead to a slower cellular decay, indicating that the acceleration of aging in $T R 4^{-1-}$ mice might stem from oxidative DNA damage via loss of functions of DNA repair systems mediated by TR4.

Mitochondrial diseases $\operatorname{PPAR} \gamma$ promotes mitochondrial biogenesis (Miglio et al. 2009) and TR4 deficiencies lead to impaired mitochondrial oxidative phosphorylation (Liu et al. 2011).
Through PGC-1 $\alpha$, an important regulator of mitochondrial biogenesis (Wu et al. 1999), PPAR $\gamma$ agonists promoted biogenesis of functional mitochondria (Miglio et al. 2009). PGC- $1 \alpha$ is rapidly induced under conditions of increased energy demands such as cold, exercise, and fasting (Ventura-Clapier et al. 2008). Mitochondrial biogenesis and respiration are stimulated by PGC- $1 \alpha$ through the powerful induction of NRF1 and NRF2 gene expression. PGC- $1 \alpha$ lacks DNA-binding ability but interacts with and co-activates numerous transcription factors including NRFs on the promoter of mtTFA (Rasbach \& Schnellmann 2007).

$T R 4^{-1-}$ mice suffer from mitochondrial myopathy and exhibit muscle weakness and exercise intolerance. An abnormal mitochondria accumulation as evidenced by ragged red fibers found in $T R 4^{-/-}$soleus muscle biopsies. In addition, increased serum lactate level, decreased mitochondrial ATP production, and decreased electron transport chain complex I (NADH: ubiquinone oxidoreductase; EC 1.6.5.3) activity were found in skeletal muscle tissues of $T R 4^{-/-}$mice. Restoring TR4 could rescue the reduction of mitochondrial ATP generation capacity and complex I enzyme activity in TR4 ${ }^{-/-}$cells. Screening complex I structure/ancillary genes revealed reduced mRNA expression of NDUFAF1, a complex I assembly factor, in tissues of $T R 4^{-/-}$mice. Mechanism studies proved that TR4 transcriptionally regulates NDUFAF1 and addition of NDUFAF1 into TR $4^{-/-}$cells restored mitochondrial ATP generation capacity and complex I activity (Liu et al. 2011).

Reproduction Female $P P A R \gamma^{-/-}$mice are infertile (Minge et al. 2008), while both male and female TR4 $4^{-/-}$ mice have reduced fertility (Collins et al. 2004, Chen et al. 2008).

PPAR $\gamma$ is required for the attachment of embryos to the endometrium for the development and function of the placenta (Barak et al. 1999). Strong PPAR $\gamma$ expression has been detected in the trophectoderm and inner-cell mass of the blastocysts. PPAR $\gamma$ inactivation leads to impaired placental vascularization, resulting in the death of the embryo. Pregnancy failure can be prevented by replacing PPAR $\gamma$-deficient placental cells with WT cells (Barak et al. 1999). PPAR $\gamma$ ligands are currently used to treat type II diabetes and also to attenuate the secondary clinical symptoms frequently associated with insulin resistance, including polycystic ovary syndrome (PCOS). Several laboratories have described strong expression of PPAR $\gamma$ in ovarian granulosa cells, and glitazones modulate granulosa cell proliferation and steroidogenesis in vitro.

Published by Bioscientifica Ltd. 
All these recent data raise new questions about the biological actions of PPARs in reproduction and their use in therapeutic treatments of fertility troubles such as PCOS or endometriosis (Froment et al. 2006).

Male $T R 4^{-/-}$mice are subfertile, which might be due to reduced sperm production at various stages (Mu et al. 2004) and have delayed spermatogenesis in the first wave of spermatogenesis from stages X to XII. But $T R 4^{-/-}$and $T R 4^{+/+}$mice show no differences in sperm morphology and cauda epididymis sperm motility. Histological examination of testis sections shows degenerated primary spermatocytes and some necrotic tubules in $T R 4^{-/-}$mice. Taken together, these findings indicate that TR4 may play essential roles in normal spermatogenesis in vivo (Mu et al. 2004).

TR4 also plays essential roles in normal female folliculogenesis and ovarian functions (Chen et al. 2008). Female $T R 4^{-1-}$ mice display subfertility, with prolonged and irregular estrous cycles, reduced size and weight of ovaries, as well as fewer or no preovulatory follicles and corpora lutea. More intensive granulosa apoptosis was found in ovaries of $T R 4^{-/-}$mice. The normal serum-luteinizing hormone (LH) and follicle-stimulating hormone (FSH) concentrations in female $T R 4^{-/-}$mice after superovulation ruled out the possibility that the subfertility of $T R 4^{-/-}$mice is due to deficiency in the pituitary gonadotropin axis. Mechanical dissection revealed that LHR is a direct TR4 target gene and that its expression in ovaries is reduced in female $T R 4^{-/-}$ mice, indicating that TR4 might play essential roles in normal folliculogenesis by modulating LHR signals (Chen et al. 2008).

\section{The advantage of having two distinct receptors activated by similar ligands}

Why does our body need two distinct NRs that can be activated via similar ligands/activators? The questions remain to be answered as to when, where, and how these two receptors are activated in response to ligands/ activators with delicate temporal and special regulation of metabolism functions.

The distinct tissue distribution pattern of PPAR $\gamma$ and TR4 might provide a hint. Take the metabolic system for example: PPAR $\gamma$ is mainly expressed in adipose tissue and controls adipocyte differentiation and function, while its role in liver is relatively limited (Gavrilova et al. 2003). In contrast, the role of TR4 in liver has been clearly demonstrated (Liu et al. 2007), yet its function in adipose tissue remains unclear. Recently, Choi et al. (2011) reported that TR4 facilitates fatty acid uptake into 3T3-L1 adipocytes via upregulation of the FATP1 gene, resulting in lipid accumulation in adipocytes. This indicates that TR4 also plays a key role in adipose physiology, although further study will be required to define its role in adipose tissue (Choi et al. 2011). Both PPAR $\gamma$ and TR4 have been shown to be involved in skeletal muscle functions (Hevener et al. 2003, Liu et al. 2011). Therefore, it is possible that these two receptors are needed for proper function in response to ligands in different tissues.

Another explanation is the timing of their expression. Previous studies show that the peak expression of TR4 and PPAR $\gamma$ is different in metabolic tissues (Table 1). In WAT, TR4 peaks at ZT4 while PPAR $\gamma$ peaks at ZT16 and in liver TR4 peaks at ZT4 while PPAR $\gamma$ peaks at ZT8. The cause and the regulatory mechanism(s) behind these cycles of expressions are not clear yet, but the expression peaks of these two receptors at different times might allow each receptor to dominate the downstream events of the ligand at different time points.

Another possibility is that even when TR4 and PPAR $\gamma$ are expressed in the same tissue at the same time, they sometimes might counteract with or cooperate with each other, which allows the flexibility to add to the complexity of ligand effects. This might be the answer to the undisclosed mystery of how the ligands can keep the subtle balance for the regulation of the complicated downstream metabolic pathway networks.

\section{The effects on the pharmaceutical industry/drug development}

The withdrawal of troglitazone from the market because of liver toxicity has led to concerns of the safety of the other TZDs. Because of this, the FDA recommends liver enzyme checks for this rare but potentially catastrophic complication every 2-3 months in the first year of TZDs therapy.

Furthermore, two newer TZDs, Avandia (rosiglitazone) and Actos (pioglitazone), have been subject to significant restrictions or warnings by the FDA (Harris 2010, FDA 2011). The major warning for Actos use is that long-term treatment may increase bladder cancer (BCa) risk. Yang et al. (2013) also recently found that PPAR $\gamma$ amplification was increased dramatically in BCa tissue compared with normal urothelium (38.1 vs $4.3 \%$ ) and in tumors with lymph node metastasis compared with those without metastasis (75.0 vs $15.4 \%$ ). Human BCa 5637 cells with strong PPAR $\gamma$ expression had better cell migration and invasion abilities than the BCa UMUC-3 cells with weak

Published by Bioscientifica Ltd. 
PPAR $\gamma$ expression. Knocking down PPAR $\gamma$ in BCa 5637 cells led to decreased cell migration and activation of PPAR $\gamma$ with TZDs promoted their migration and invasive ability, indicating that $\operatorname{PPAR} \gamma$ and its ligand TZD may play a positive role in promoting $\mathrm{BCa}$ progression (Yang et al. 2013).

Other side effects of TZDs include edema, anemia, body pain, fatigue, weight gain, jaundice, headache, stomach upset and the worst, heart failure. Therefore, TZDs should be prescribed with both caution and patient warnings about the potential for water retention/weight gain and other side effects, especially in patients with decreased ventricular function (NYHA grade III or IV heart failure).

As the current insulin sensitizer, TZDs can activate their downstream targets through both TR4 and PPAR $\gamma$; this might be part of the reason behind the drug side effects. In this scenario, treatment with TZDs can activate both TR4 and PPAR $\gamma$ signals, and thus alter their interactions with each other in the body, to either strengthen each other on some occasions or counteract each other on other occasions, all of which might be dependent on the cellular context. Although the detailed mechanisms need further exploration, the side effects of TZDs might be partly explained by our unexpected findings, showing the unbalanced regulation of PPAR $\gamma$ and TR4, which has not been previously acknowledged (SJ Lin , K Izumi, H Miyamoto, N Wang and C Chang unpublished observations).

Considering the physiological importance of both receptors in mediating the metabolic syndrome and their affinity for similar ligands/activators, it might be necessary to test both PPAR $\gamma$ and TR4 response when developing the new generation of PPAR $\gamma$-targeting anti-diabetic drugs. A better characterization of each of these two NRs and the interaction between them might help to reduce the side effects and gain better potency.

\section{Summary and future perspectives}

Early studies indicated a role of PPAR $\gamma$ in adipocyte function because of its high expression in adipocytes and its ability to stimulate adipocyte differentiation of cultured fibroblasts (Tontonoz et al. 1994a,b). Subsequent studies identified a natural adipogenic regulator, PUFA and its metabolite, $15 \mathrm{~d}-\mathrm{PGJ}_{2}$ as ligands/activators of PPAR $\gamma$ (Forman et al. 1995, Kliewer et al. 1995, Lehmann et al. 1995). Several PPAR $\gamma$ agonists, including members of the TZDs family, such as the antidiabetic drug rosiglitazone, were then developed to battle metabolic diseases.
Previous in vitro and in vivo studies indicated that TR4 plays essential roles in postnatal growth, neural development, spermatogenesis, metabolism, skeletal muscle function, and bone remodeling (Collins et al. 2004, Mu et al. 2004, Chen et al. 2005, Kim et al. 2005, Zhang et al. 2007). TR4 has long been viewed as an orphan receptor, until the recent discovery that the PPAR $\gamma$ ligands/activators, such as PUFAs and its metabolites, 15-HETE and 13-HODE, as well as rosiglitazone, could also transactivate TR4 to a similar degree to their activation of PPAR $\gamma$ (Xie et al. 2009). This result further confirmed previous findings that TR4 is important in insulin sensitivity, glucose metabolism (Liu et al. 2007), and lipid metabolism (Kim et al. 2011).

Most of previous studies regarding TR4's role in metabolism focus on the liver, while the action of TR 4 in adipose tissues is largely unknown. After the identification of PUFAs, 15-HETE and 13-HODE, as the new TR4 ligands/activators, we need to look into the role of TR4 in adipose tissues, considering the high abundances of the ligands/activators there. Also, future studies on the effects of TZDs in tissue-specific TR4-knockout mice will improve our understanding of how TZDs work and TR4's physiological and pathological roles in response to TZDs.

Although sharing similar ligands/activators, TR4 and $\operatorname{PPAR} \gamma$ could trigger similar or distinct downstream signals, depending on the context. While TZDs improve insulin sensitivity through the activation of PPAR $\gamma$ and its downstream pathways in adipose tissues, they might trigger some side effects in other tissues by the unexpected activation of TR4. Thus, it is extremely important to fully understand the details of the spatial and temporal action of TZDs on TR4 and PPAR $\gamma$, the respective consequent downstream events following their activation, and the interaction between these two signaling networks. With this knowledge in hand, the drug industry might be able to improve drug specificity and reduce side effects of the old TZDs drugs possibly by limiting the 'bad' effects of TR4. It might be possible to develop new therapeutic approaches for metabolic and other diseases by targeting either TR4 or PPAR $\gamma$ in specific tissues.

Declaration of interest

The authors declare that there is no conflict of interest that could be perceived as prejudicing the impartiality of the review.

\section{Funding}

This work was supported by the National Institutes of Health grant CA156700 awarded to C. Chang.

Published by Bioscientifica Ltd. 


\section{References}

Abdelrahman M, Sivarajah A \& Thiemermann C 2005 Beneficial effects of PPAR- $\gamma$ ligands in ischemia-reperfusion injury, inflammation and shock. Cardiovascular Research 65 772-781. (doi:10.1016/j.cardiores. 2004.12.008)

Adams M, Reginato MJ, Shao D, Lazar MA \& Chatterjee VK 1997 Transcriptional activation by peroxisome proliferator-activated receptor $\gamma$ is inhibited by phosphorylation at a consensus mitogenactivated protein kinase site. Journal of Biological Chemistry 272 5128-5132. (doi:10.1074/jbc.272.43.27295)

Ahmed RA, Murao K, Imachi H, Yu X, Li J, Wong NC \& Ishida T 2009 Human scavenger receptor class $\mathrm{b}$ type 1 is regulated by activators of peroxisome proliferators-activated receptor- $\gamma$ in hepatocytes. Endocrine 35 233-242. (doi:10.1007/s12020-008-9142-2)

Akahoshi T, Namai R, Murakami Y, Watanabe M, Matsui T, Nishimura A, Kitasato H, Kameya T \& Kondo H 2003 Rapid induction of peroxisome proliferator-activated receptor $\gamma$ expression in human monocytes by monosodium urate monohydrate crystals. Arthritis and Rheumatism 48 231-239. (doi:10.1002/art.10709)

Amin RH, Mathews ST, Camp HS, Ding L \& Leff T 2010 Selective activation of PPAR $\gamma$ in skeletal muscle induces endogenous production of adiponectin and protects mice from diet-induced insulin resistance. American Journal of Physiology. Endocrinology and Metabolism 298 E28-E37. (doi:10.1152/ajpendo.00446.2009)

Barak Y, Nelson MC, Ong ES, Jones YZ, Ruiz-Lozano P, Chien KR, Koder A \& Evans RM 1999 PPAR $\gamma$ is required for placental, cardiac, and adipose tissue development. Molecular Cell 4 585-595. (doi:10.1016/S10972765(00)80209-9)

Bays H, Mandarino L \& DeFronzo RA 2004 Role of the adipocyte, free fatty acids, and ectopic fat in pathogenesis of type 2 diabetes mellitus: peroxisomal proliferator-activated receptor agonists provide a rational therapeutic approach. Journal of Clinical Endocrinology and Metabolism 89 463-478. (doi:10.1210/jc.2003-030723)

Bell-Parikh LC, Ide T, Lawson JA, McNamara P, Reilly M \& FitzGerald GA 2003 Biosynthesis of 15 -deoxy- $\Delta 12,14-\mathrm{PGJ}_{2}$ and the ligation of PPAR $\gamma$. Journal of Clinical Investigation 112 945-955. (doi:10.1172/ JCI200318012)

Bonofiglio D, Gabriele S, Aquila S, Catalano S, Gentile M, Middea E, Giordano F \& Ando S 2005 Estrogen receptor $\alpha$ binds to peroxisome proliferator-activated receptor response element and negatively interferes with peroxisome proliferator-activated receptor $\gamma$ signaling in breast cancer cells. Clinical Cancer Research 11 6139-6147. (doi:10.1158/1078-0432.CCR-04-2453)

Bookout AL, Jeong Y, Downes M, Yu RT, Evans RM \& Mangelsdorf DJ 2005 Tissue-specific expression patterns of nuclear receptors. www.nursa. org/10.1621/datasets.02001.

Bookout AL, Jeong Y, Downes M, Yu RT, Evans RM \& Mangelsdorf DJ 2006 Anatomical profiling of nuclear receptor expression reveals a hierarchical transcriptional network. Cell 126 789-799. (doi:10.1016/ j.cell.2006.06.049)

Booth AM, Caldwell SH \& Iezzoni JC 2000 Troglitazone-associated hepatic failure. American Journal of Gastroenterology 95 557-558. (doi:10.1111/ j.1572-0241.2000.t01-1-01806.x)

Bordet R, Ouk T, Petrault O, Gelé P, Gautier S, Laprais M, Deplanque D, Duriez P, Staels B, Fruchart JC et al. 2006 PPAR: a new pharmacological target for neuroprotection in stroke and neurodegenerative diseases. Biochemical Society Transactions 34 1341-1346. (doi:10.1042/ BST0341341)

Bragt MC \& Popeijus HE 2008 Peroxisome proliferator-activated receptors and the metabolic syndrome. Physiology \& Behavior 94 187-197. (doi:10.1016/j.physbeh.2007.11.053)

Camp HS \& Tafuri SR 1997 Regulation of peroxisome proliferator-activated receptor $\gamma$ activity by mitogen-activated protein kinase. Journal of Biological Chemistry 272 10811-10816. (doi:10.1074/jbc.272.16.10811)

http://erc.endocrinology-journals.org DOI: 10.1530/ERC-13-0529 (c) 2014 Society for Endocrinology Printed in Great Britain
Camp HS, Tafuri SR \& Leff T 1999 c-Jun N-terminal kinase phosphorylates peroxisome proliferator-activated receptor- $\gamma 1$ and negatively regulates its transcriptional activity. Endocrinology 140 392-397. (doi:10.1210/ en.140.1.392)

Chang C \& Kokontis J 1988 Identification of a new member of the steroid receptor super-family by cloning and sequence analysis. Biochemical and Biophysical Research Communications 155 971-977. (doi:10.1016/ S0006-291X(88)80591-6)

Chang C, Kokontis J, Acakpo-Satchivi L, Liao S, Takeda H \& Chang Y 1989 Molecular cloning of new human TR2 receptors: a class of steroid receptor with multiple ligand-binding domains. Biochemical and Biophysical Research Communications 165 735-741. (doi:10.1016/ S0006-291X(89)80028-2)

Chang C, Da Silva SL, Ideta R, Lee Y, Yeh S \& Burbach JP 1994 Human and rat TR4 orphan receptors specify a subclass of the steroid receptor superfamily. PNAS 91 6040-6044. (doi:10.1073/pnas.91.13.6040)

Chawla A, Boisvert WA, Lee CH, Laffitte BA, Barak Y, Joseph SB, Liao D, Nagy L, Edwards PA, Curtiss LK et al. 2001 A PPAR $\gamma$-LXR-ABCA1 pathway in macrophages is involved in cholesterol efflux and atherogenesis. Molecular Cell 7 161-171. (doi:10.1016/S10972765(01)00164-2)

Chen YT, Collins LL, Uno H \& Chang C 2005 Deficits in motor coordination with aberrant cerebellar development in mice lacking testicular orphan nuclear receptor 4. Molecular and Cellular Biology 25 2722-2732. (doi:10.1128/MCB.25.7.2722-2732.2005)

Chen YT, Collins LL, Uno H, Chou SM, Meshul CK, Chang SS \& Chang C 2007 Abnormal cerebellar cytoarchitecture and impaired inhibitory signaling in adult mice lacking TR4 orphan nuclear receptor. Brain Research 1168 72-82. (doi:10.1016/j.brainres.2007.06.069)

Chen L-M, Wang R-S, Lee Y-F, Liu N-C, Chang Y-J, Wu C-C, Xie S, Hung Y-C \& Chang C 2008 Subfertility with defective folliculogenesis in female mice lacking testicular orphan nuclear receptor 4. Molecular Endocrinology 22 858-867. (doi:10.1210/me.2007-0181)

Choi H, Kim SJ, Park SS, Chang C \& Kim E 2011 TR4 activates FATP1 gene expression to promote lipid accumulation in 3T3-L1 adipocytes. FEBS Letters 585 2763-2767. (doi:10.1016/j.febslet.2011.08.002)

Cohen P \& Friedman JM 2004 Leptin and the control of metabolism: role for stearoyl-CoA desaturase-1 (SCD-1). Journal of Nutrition 134 2455S-2463S.

Cohen P, Ntambi JM \& Friedman JM 2003 Stearoyl-CoA desaturase-1 and the metabolic syndrome. Current Drug Targets. Immune, Endocrine and Metabolic Disorders 3 271-280. (doi:10.2174/1568008033340117)

Collins LL, Lee YF, Heinlein CA, Liu NC, Chen YT, Shyr CR, Meshul CK, Uno H, Platt KA \& Chang C 2004 Growth retardation and abnormal maternal behavior in mice lacking testicular orphan nuclear receptor 4. PNAS 101 15058-15063. (doi:10.1073/pnas. 0405700101)

Debril MB, Dubuquoy L, Feige JN, Wahli W, Desvergne B, Auwerx J \& Gelman L 2005 Scaffold attachment factor B1 directly interacts with nuclear receptors in living cells and represses transcriptional activity. Journal of Molecular Endocrinology 35 503-517. (doi:10.1677/ jme.1.01856)

Demetri GD, Fletcher CD, Mueller E, Sarraf P, Naujoks R, Campbell N, Spiegelman BM \& Singer S 1999 Induction of solid tumor differentiation by the peroxisome proliferator-activated receptor- $\gamma$ ligand troglitazone in patients with liposarcoma. PNAS 96 3951-3956. (doi:10.1073/pnas.96.7.3951)

Desvergne B \& Wahli W 1999 Peroxisome proliferator-activated receptors: nuclear control of metabolism. Endocrine Reviews 20 649-688. (doi:10.1210/edrv.20.5.0380)

Dolezalova R, Haluzik MM, Bosanska L, Lacinova Z, Kasalova Z, Stulc T \& Haluzik M 2007 Effect of PPAR- $\gamma$ agonist treatment on markers of endothelial dysfunction in patients with type 2 diabetes mellitus. Physiological Research 56 741-748.

Dreyer C, Krey G, Keller H, Givel F, Helftenbein G \& Wahli W 1992 Control of the peroxisomal $\beta$-oxidation pathway by a novel family 
of nuclear hormone receptors. Cell 68 879-887. (doi:10.1016/ 0092-8674(92)90031-7)

Du J, Zhang L \& Wang Z 2009 Testosterone inhibits the activity of peroxisome proliferator-activated receptor $\gamma$ in a transcriptional transaction assay. Die Pharmazie 64 692-693.

Dutchak PA, Katafuchi T, Bookout AL, Choi JH, Yu RT, Mangelsdorf DJ \& Kliewer SA 2012 Fibroblast growth factor-21 regulates PPAR $\gamma$ activity and the antidiabetic actions of thiazolidinediones. Cell 148 556-567. (doi:10.1016/j.cell.2011.11.062)

Fajas L, Auboeuf D, Raspe E, Schoonjans K, Lefebvre AM, Saladin R, Najib J, Laville M, Fruchart JC, Deeb S et al. 1997 The organization, promoter analysis, and expression of the human PPAR $\gamma$ gene. Journal of Biological Chemistry 272 18779-18789. (doi:10.1074/jbc.272. 30.18779)

FDA 2011 Update to ongoing safety review of Actos (pioglitazone) and increased risk of bladder cancer. FDA Drug Safety Communication. Silver Spring: FDA.

Feige JN \& Auwerx J 2007 Transcriptional coregulators in the control of energy homeostasis. Trends in Cell Biology 17 292-301. (doi:10.1016/ j.tcb.2007.04.001)

Ferre P 2004 The biology of peroxisome proliferator-activated receptors: relationship with lipid metabolism and insulin sensitivity. Diabetes 53 (Suppl 1) S43-S50. (doi:10.2337/diabetes.53.2007.S43)

Ferry G, Bruneau V, Beauverger P, Goussard M, Rodriguez M, Lamamy V, Dromaint S, Canet E, Galizzi J-P \& Boutin JA 2001 Binding of prostaglandins to human PPAR $\gamma$ : tool assessment and new natural ligands. European Journal of Pharmacology 417 77-89. (doi:10.1016/ S0014-2999(01)00907-4)

Fitzpatrick F \& Wynalda M 1983 Albumin-catalyzed metabolism of prostaglandin D2, Identification of products formed in vitro. Journal of Biological Chemistry 258 11713-11718.

Floyd ZE \& Stephens JM 2002 Interferon- $\gamma$-mediated activation and ubiquitin-proteasome-dependent degradation of PPAR $\gamma$ in adipocytes. Journal of Biological Chemistry 277 4062-4068. (doi:10.1074/jbc. M108473200)

Forman BM, Tontonoz P, Chen J, Brun RP, Spiegelman BM \& Evans RM 1995 15-Deoxy- $\Delta 12,14$-prostaglandin $\mathrm{J}_{2}$ is a ligand for the adipocyte determination factor PPAR $\gamma$. Cell 83 803-812. (doi:10.1016/00928674(95)90193-0)

Foryst-Ludwig A, Clemenz M, Hohmann S, Hartge M, Sprang C, Frost N, Krikov M, Bhanot S, Barros R, Morani A et al. 2008 Metabolic actions of estrogen receptor $\beta$ (ER $\beta)$ are mediated by a negative cross-talk with PPAR $\gamma$. PLoS Genetics 4 e1000108. (doi:10.1371/journal.pgen. 1000108)

Francis GA, Annicotte JS \& Auwerx J 2003 PPAR agonists in the treatment of atherosclerosis. Current Opinion in Pharmacology 3 186-191. (doi:10.1016/S1471-4892(03)00014-6)

Froment P, Gizard F, Defever D, Staels B, Dupont J \& Monget P 2006 Peroxisome proliferator-activated receptors in reproductive tissues: from gametogenesis to parturition. Journal of Endocrinology 189 199-209. (doi:10.1677/joe.1.06667)

Gampe RT Jr, Montana VG, Lambert MH, Miller AB, Bledsoe RK, Milburn MV, Kliewer SA, Willson TM \& Xu HE 2000 Asymmetry in the $\operatorname{PPAR} \gamma / \operatorname{RXR} \alpha$ crystal structure reveals the molecular basis of heterodimerization among nuclear receptors. Molecular Cell 5 545-555. (doi:10.1016/S1097-2765(00)80448-7)

Gavrilova O, Haluzik M, Matsusue K, Cutson JJ, Johnson L, Dietz KR, Nicol CJ, Vinson C, Gonzalez FJ \& Reitman ML 2003 Liver peroxisome proliferator-activated receptor $\gamma$ contributes to hepatic steatosis, triglyceride clearance, and regulation of body fat mass. Journal of Biological Chemistry 278 34268-34276. (doi:10.1074/jbc.M300043200)

Granberry MC, Hawkins JB \& Franks AM 2007 Thiazolidinediones in patients with type 2 diabetes mellitus and heart failure. American Journal of Health-System Pharmacy 64 931-936. (doi:10.2146/ ajhp060446)
Guan HP, Ishizuka T, Chui PC, Lehrke M \& Lazar MA 2005 Corepressors selectively control the transcriptional activity of PPAR $\gamma$ in adipocytes. Genes and Development 19 453-461. (doi:10.1101/gad.1263305)

Gupta P, Ho PC, Huq MM, Ha SG, Park SW, Khan AA, Tsai NP \& Wei LN 2008 Retinoic acid-stimulated sequential phosphorylation, PML recruitment, and SUMOylation of nuclear receptor TR2 to suppress Oct4 expression. PNAS 105 11424-11429. (doi:10.1073/pnas. 0710561105)

Hankey BF, Feuer EJ, Clegg LX, Hayes RB, Legler JM, Prorok PC, Ries LA, Merrill RM \& Kaplan RS 1999 Cancer surveillance series: interpreting trends in prostate cancer - part I: evidence of the effects of screening in recent prostate cancer incidence, mortality, and survival rates. Journal of the National Cancer Institute 91 1017-1024. (doi:10.1093/ jnci/91.12.1017)

Harris H 2010 Research ties diabetes drug to heart woes. New York Times. 19 February 2010.

Hartig SM, He B, Long W, Buehrer BM \& Mancini MA 2011 Homeostatic levels of SRC-2 and SRC-3 promote early human adipogenesis. Journal of Cell Biology 192 55-67. (doi:10.1083/jcb.201004026)

Hauner H 2002 The mode of action of thiazolidinediones. Diabetes/Metabolism Research and Reviews 18 (Suppl 2) S10-S15. (doi:10.1002/dmrr.249)

Hauser S, Adelmant G, Sarraf P, Wright HM, Mueller E \& Spiegelman BM 2000 Degradation of the peroxisome proliferator-activated receptor $\gamma$ is linked to ligand-dependent activation. Journal of Biological Chemistry 275 18527-18533. (doi:10.1074/jbc.M001297200)

Hevener AL, He W, Barak Y, Le J, Bandyopadhyay G, Olson P, Wilkes J, Evans RM \& Olefsky J 2003 Muscle-specific Pparg deletion causes insulin resistance. Nature Medicine 9 1491-1497. (doi:10.1038/ nm956)

Hirose T, Fujimoto W, Tamaai T, Kim KH, Matsuura H \& Jetten AM 1994 TAK1: molecular cloning and characterization of a new member of the nuclear receptor superfamily. Molecular Endocrinology 8 1667-1680. (doi:10.1210/mend.8.12.7708055)

Hou Y, Moreau F \& Chadee K 2012 PPAR $\gamma$ is an E3 ligase that induces the degradation of NFkB/p65. Nature Communications 3 1300. (doi:10.1038/ ncomms2270)

Houston KD, Copland JA, Broaddus RR, Gottardis MM, Fischer SM \& Walker CL 2003 Inhibition of proliferation and estrogen receptor signaling by peroxisome proliferator-activated receptor $\gamma$ ligands in uterine leiomyoma. Cancer Research 63 1221-1227.

Huang YH, Liao CH, Chen RN, Liao CJ \& Lin KH 2010 Human testicular orphan receptor 4 enhances thyroid hormone receptor signaling. Journal of Cellular Physiology 222 347-356. (doi:10.1002/ jсp.21959)

Huq MDM, Gupta P, Tsai N-P \& Wei L-N 2006 Modulation of testicular receptor 4 activity by mitogen-activated protein kinase-mediated phosphorylation. Molecular and Cellular Proteomics 5 2072-2082. (doi:10.1074/mcp.M600180-MCP200)

Ideta R, Yeh S, Lee Y, Adachi K, Takeda H, Su C, Saltzman A \& Chang C 1995 Gene expression of the androgen repressed rat TR2 orphan receptor: a member of steroid receptor superfamily. Endocrine 3 277-283. (doi:10.1007/BF03021406)

Issemann I \& Green S 1990 Activation of a member of the steroid hormone receptor superfamily by peroxisome proliferators. Nature $\mathbf{3 4 7} 645-650$. (doi:10.1038/347645a0)

Jennewein C, Kuhn AM, Schmidt MV, Meilladec-Jullig V, von Knethen A, Gonzalez FJ \& Brune B 2008 Sumoylation of peroxisome proliferator-activated receptor $\gamma$ by apoptotic cells prevents lipopolysaccharide-induced $\mathrm{NCoR}$ removal from $\kappa \mathrm{B}$ binding sites mediating transrepression of proinflammatory cytokines. Journal of Immunology 181 5646-5652. (doi:10.4049/jimmunol.181.8.5646)

Jeong S \& Yoon M 2011 17ß-Estradiol inhibition of PPAR $\gamma$-induced adipogenesis and adipocyte-specific gene expression. Acta Pharmacologica Sinica 32 230-238. (doi:10.1038/aps.2010.198) 
Jiang G \& Hunter T 1999 Receptor signaling: when dimerization is not enough. Current Biology 9 R568-R571. (doi:10.1016/S09609822(99)80357-1)

Jiang C, Ting AT \& Seed B 1998 PPAR- $\gamma$ agonists inhibit production of monocyte inflammatory cytokines. Nature 391 82-86. (doi:10.1038/ 35154)

Kersten S, Desvergne B \& Wahli W 2000 Roles of PPARs in health and disease. Nature 405 421-424. (doi:10.1038/35013000)

Kielian T \& Drew PD 2003 Effects of peroxisome proliferator-activated receptor- $\gamma$ agonists on central nervous system inflammation. Journal of Neuroscience Research 71 315-325. (doi:10.1002/jnr.10501)

Kim E, Xie S, Yeh S-D, Lee Y-F, Collins LL, Hu Y-C, Shyr C-R, Mu X-M, Liu N-C, Chen Y-T et al. 2003 Disruption of TR4 orphan nuclear receptor reduces the expression of liver apolipoprotein E/C-I/C-II gene cluster. Journal of Biological Chemistry 278 46919-46926. (doi:10.1074/ jbc.M304088200)

Kim E, Yang Z, Liu NC \& Chang C 2005 Induction of apolipoprotein E expression by TR4 orphan nuclear receptor via $5^{\prime}$ proximal promoter region. Biochemical and Biophysical Research Communications 328 85-90. (doi:10.1016/j.bbrc.2004.12.146)

Kim HJ, Hwang JY, Choi WS, Lee JH, Chang KC, Nishinaka T, Yabe-Nishimura C \& Seo HG 2007 Expression of a peroxisome proliferator-activated receptor $\gamma 1$ splice variant that was identified in human lung cancers suppresses cell death induced by cisplatin and oxidative stress. Clinical Cancer Research 13 2577-2583. (doi:10.1158/ 1078-0432.CCR-06-2062)

Kim E, Liu NC, Yu IC, Lin HY, Lee YF, Sparks JD, Chen LM \& Chang C 2011 Metformin inhibits nuclear receptor TR4-mediated hepatic stearoylCoA desaturase 1 gene expression with altered insulin sensitivity. Diabetes 60 1493-1503. (doi:10.2337/db10-0393)

Kintscher U, Goetze S, Wakino S, Kim S, Nagpal S, Chandraratna RA, Graf K, Fleck E, Hsueh WA \& Law RE 2000 Peroxisome proliferatoractivated receptor and retinoid $X$ receptor ligands inhibit monocyte chemotactic protein-1-directed migration of monocytes. European Journal of Pharmacology 401 259-270. (doi:10.1016/S00142999(00)00461-1)

Kliewer SA, Umesono K, Noonan DJ, Heyman RA \& Evans RM 1992 Convergence of 9-cis retinoic acid and peroxisome proliferator signalling pathways through heterodimer formation of their receptors. Nature 358 771-774. (doi:10.1038/358771a0)

Kliewer SA, Lenhard JM, Willson TM, Patel I, Morris DC \& Lehmann JM 1995 A prostaglandin $\mathrm{J}_{2}$ metabolite binds peroxisome proliferatoractivated receptor $\gamma$ and promotes adipocyte differentiation. Cell $\mathbf{8 3}$ 813-819. (doi:10.1016/0092-8674(95)90194-9)

Kliewer SA, Sundseth SS, Jones SA, Brown PJ, Wisely GB, Koble CS, Devchand P, Wahli W, Willson TM, Lenhard JM et al. 1997 Fatty acids and eicosanoids regulate gene expression through direct interactions with peroxisome proliferator-activated receptors $\alpha$ and $\gamma$. PNAS 94 4318-4323. (doi:10.1073/pnas.94.9.4318)

Koeffler HP 2003 Peroxisome proliferator-activated receptor $\gamma$ and cancers. Clinical Cancer Research 9 1-9.

Krey G, Braissant O, L'Horset F, Kalkhoven E, Perroud M, Parker MG \& Wahli W 1997 Fatty acids, eicosanoids, and hypolipidemic agents identified as ligands of peroxisome proliferator-activated receptors by coactivator-dependent receptor ligand assay. Molecular Endocrinology 11 779-791. (doi:10.1210/mend.11.6.0007)

Kubota N, Terauchi Y, Miki H, Tamemoto H, Yamauchi T, Komeda K, Satoh S, Nakano R, Ishii C, Sugiyama T et al. 1999 PPAR $\gamma$ mediates high-fat diet-induced adipocyte hypertrophy and insulin resistance. Molecular Cell 4 597-609. (doi:10.1016/S1097-2765(00)80210-5)

Kurosu H, Yamamoto M, Clark JD, Pastor JV, Nandi A, Gurnani P, McGuinness OP, Chikuda H, Yamaguchi M, Kawaguchi H et al. 2005 Suppression of aging in mice by the hormone Klotho. Science $\mathbf{3 0 9}$ 1829-1833. (doi:10.1126/science.1112766)

Lai PH, Wang WL, Ko CY, Lee YC, Yang WM, Shen TW, Chang WC \& Wang JM 2008 HDAC1/HDAC3 modulates PPARG2 transcription

http://erc.endocrinology-journals.org DOI: 10.1530/ERC-13-0529
(C) 2014 Society for Endocrinology Printed in Great Britain through the sumoylated CEBPD in hepatic lipogenesis. Biochimica et Biophysica Acta 1783 1803-1814. (doi:10.1016/j.bbamcr. 2008.06.008)

Lazennec G, Canaple L, Saugy D \& Wahli W 2000 Activation of peroxisome proliferator-activated receptors (PPARs) by their ligands and protein kinase A activators. Molecular Endocrinology 14 1962-1975. (doi:10.1210/mend.14.12.0575)

Lecomte J, Flament S, Salamone S, Boisbrun M, Mazerbourg S, Chapleur Y \& Grillier-Vuissoz I 2008 Disruption of ER $\alpha$ signalling pathway by PPAR $\gamma$ agonists: evidences of PPAR $\gamma$-independent events in two hormonedependent breast cancer cell lines. Breast Cancer Research and Treatment 112 437-451. (doi:10.1007/s10549-007-9886-z)

Lee H-J, Lee Y, Burbach JPH \& Chang C 1995 Suppression of gene expression on the simian virus 40 major late promoter by human TR4 orphan receptor. Journal of Biological Chemistry 270 30129-30133. (doi:10.1074/jbc.270.50.30129)

Lee C-H, Chinpaisal C \& Wei L-N 1998 A novel nuclear receptor heterodimerization pathway mediated by orphan receptors TR2 and TR4. Journal of Biological Chemistry 273 25209-25215. (doi:10.1074/jbc. 273.39.25209)

Lee Y-F, Shyr C-R, Thin TH, Lin W-J \& Chang C 1999 Convergence of two repressors through heterodimer formation of androgen receptor and testicular orphan receptor-4: a unique signaling pathway in the steroid receptor superfamily. PNAS 96 14724-14729. (doi:10.1073/pnas.96. 26.14724)

Lee YF, Lee HJ \& Chang C 2002 Recent advances in the TR2 and TR4 orphan receptors of the nuclear receptor superfamily. Journal of Steroid Biochemistry and Molecular Biology 81 291-308. (doi:10.1016/ S0960-0760(02)00118-8)

Lee C-H, Olson P \& Evans RM 2003 Minireview: lipid metabolism, metabolic diseases, and peroxisome proliferator-activated receptors. Endocrinology 144 2201-2207. (doi:10.1210/en.2003-0288)

Lee YF, Liu S, Liu NC, Wang RS, Chen LM, Lin WJ, Ting HJ, Ho HC, Li G, Puzas EJ et al. 2011 Premature aging with impaired oxidative stress defense in mice lacking TR4. American Journal of Physiology. Endocrinology and Metabolism 301 E91-E98. (doi:10.1152/ajpendo.00701.2010)

Leff T 2003 AMP-activated protein kinase regulates gene expression by direct phosphorylation of nuclear proteins. Biochemical Society Transactions 31 224-227. (doi:10.1042/BST0310224)

Lehmann JM, Moore LB, Smith-Oliver TA, Wilkison WO, Willson TM \& Kliewer SA 1995 An antidiabetic thiazolidinedione is a high affinity ligand for peroxisome proliferator-activated receptor $\gamma$ (PPAR $\gamma)$. Journal of Biological Chemistry 270 12953-12956. (doi:10.1074/jbc. 270.50.30221)

Li AC, Brown KK, Silvestre MJ, Willson TM, Palinski W \& Glass CK 2000 Peroxisome proliferator-activated receptor $\gamma$ ligands inhibit development of atherosclerosis in LDL receptor-deficient mice. Journal of Clinical Investigation 106 523-531. (doi:10.1172/JCI10370)

Li Z, Kruijt JK, van der Sluis RJ, Van Berkel TJ \& Hoekstra M 2013 Nuclear receptor atlas of female mouse liver parenchymal, endothelial, and Kupffer cells. Physiological Genomics 45 268-275. (doi:10.1152/physiolgenomics.00151.2012)

Lin SJ, Lee SO, Lee YF, Miyamoto H, Yang DR, Li G \& Chang C 2014 TR4 is a tumor suppressor of prostate tumorigenesis via modulation of DNA damage/repair system. Carcinogenesis [in press]. (doi:10.1093/carcin/ bgu052)

Liu NC, Lin WJ, Kim E, Collins LL, Lin HY, Yu IC, Sparks JD, Chen LM, Lee YF \& Chang C 2007 Loss of TR4 orphan nuclear receptor reduces phosphoenolpyruvate carboxykinase-mediated gluconeogenesis. Diabetes 56 2901-2909. (doi:10.2337/db07-0359)

Liu NC, Lin WJ, Yu IC, Lin HY, Liu S, Lee YF \& Chang C 2009 Activation of TR4 orphan nuclear receptor gene promoter by cAMP/PKA and C/EBP signaling. Endocrine 36 211-217. (doi:10.1007/s12020-009-9220-0)

Liu S, Lee YF, Chou S, Uno H, Li G, Brookes P, Massett MP, Wu Q, Chen LM \& Chang C 2011 Mice lacking TR4 nuclear receptor develop 
mitochondrial myopathy with deficiency in complex I. Molecular Endocrinology 25 1301-1310. (doi:10.1210/me.2010-0455)

Lyles BE, Akinyeke TO, Moss PE \& Stewart LV 2009 Thiazolidinediones regulate expression of cell cycle proteins in human prostate cancer cells via PPAR $\gamma$-dependent and PPAR $\gamma$-independent pathways. Cell Cycle 8 268-277. (doi:10.4161/cc.8.2.7584)

Maeda N, Takahashi M, Funahashi T, Kihara S, Nishizawa H, Kishida K, Nagaretani H, Matsuda M, Komuro R, Ouchi N et al. 2001 PPAR $\gamma$ ligands increase expression and plasma concentrations of adiponectin, an adipose-derived protein. Diabetes 50 2094-2099. (doi:10.2337/ diabetes.50.9.2094)

Matthews L, Berry A, Tersigni M, D'Acquisto F, Ianaro A \& Ray D 2009 Thiazolidinediones are partial agonists for the glucocorticoid receptor. Endocrinology 150 75-86. (doi:10.1210/en.2008-0196)

Miglio G, Rosa AC, Rattazzi L, Collino M, Lombardi G \& Fantozzi R 2009 $\operatorname{PPAR} \gamma$ stimulation promotes mitochondrial biogenesis and prevents glucose deprivation-induced neuronal cell loss. Neurochemistry International 55 496-504. (doi:10.1016/j.neuint.2009.05.001)

Minge CE, Robker RL \& Norman RJ 2008 PPAR $\gamma$ : coordinating metabolic and immune contributions to female fertility. PPAR Research 2008 243791. (doi:10.1155/2008/243791)

Misra P, Owuor ED, Li W, Yu S, Qi C, Meyer K, Zhu Y-J, Rao MS, Kong A-NT \& Reddy JK 2002 Phosphorylation of transcriptional coactivator peroxisome proliferator-activated receptor (PPAR)-binding protein (PBP), Stimulation of transcriptional regulation by mitogen-activated protein kinase. Journal of Biological Chemistry 277 48745-48754. (doi:10.1074/jbc.M208829200)

Moore KJ, Rosen ED, Fitzgerald ML, Randow F, Andersson LP, Altshuler D, Milstone DS, Mortensen RM, Spiegelman BM \& Freeman MW 2001 The role of PPAR- $\gamma$ in macrophage differentiation and cholesterol uptake. Nature Medicine 7 41-47. (doi:10.1038/83328)

Moore KJ, Sheedy FJ \& Fisher EA 2013 Macrophages in atherosclerosis: a dynamic balance. Nature Reviews. Immunology 13 709-721. (doi:10.1038/nri3520)

Mu X, Lee YF, Liu NC, Chen YT, Kim E, Shyr CR \& Chang C 2004 Targeted inactivation of testicular nuclear orphan receptor 4 delays and disrupts late meiotic prophase and subsequent meiotic divisions of spermatogenesis. Molecular and Cellular Biology 24 5887-5899. (doi:10.1128/ МСB.24.13.5887-5899.2004)

Nagy L, Tontonoz P, Alvarez JGA, Chen H \& Evans RM 1998 Oxidized LDL regulates macrophage gene expression through ligand activation of PPAR $\gamma$. Cell 93 229-240. (doi:10.1016/S0092-8674(00)81574-3)

Nakajima T, Fujino S, Nakanishi G, Kim Y-S \& Jetten AM 2004 TIP27: a novel repressor of the nuclear orphan receptor TAK1/TR4. Nucleic Acids Research 32 4194-4204. (doi:10.1093/nar/gkh741)

Neve BP, Fruchart JC \& Staels B 2000 Role of the peroxisome proliferatoractivated receptors (PPAR) in atherosclerosis. Biochemical Pharmacology 60 1245-1250. (doi:10.1016/S0006-2952(00)00430-5)

Nicholson AC \& Hajjar DP 2004 CD36, oxidized LDL, and PPAR $\gamma$ : pathological interactions in macrophages and atherosclerosis. Vascular Pharmacology 41 139-146. (doi:10.1016/j.vph.2004.08.003)

Nie M, Corbett L, Knox AJ \& Pang L 2005 Differential regulation of chemokine expression by peroxisome proliferator-activated receptor $\gamma$ agonists: interactions with glucocorticoids and $\beta 2$-agonists. Journal of Biological Chemistry 280 2550-2561. (doi:10.1074/jbc.M410616200)

Nolan JJ, Ludvik B, Beerdsen P, Joyce M \& Olefsky J 1994 Improvement in glucose tolerance and insulin resistance in obese subjects treated with troglitazone. New England Journal of Medicine 331 1188-1193. (doi:10.1056/NEJM199411033311803)

Nolte RT, Wisely GB, Westin S, Cobb JE, Lambert MH, Kurokawa R, Rosenfeld MG, Willson TM, Glass CK \& Milburn MV 1998 Ligand binding and co-activator assembly of the peroxisome proliferatoractivated receptor- $\gamma$. Nature 395 137-143. (doi:10.1038/25931)

Oakes ND, Thalen PG, Jacinto SM \& Ljung B 2001 Thiazolidinediones increase plasma-adipose tissue FFA exchange capacity and enhance insulin-mediated control of systemic FFA availability. Diabetes $\mathbf{5 0}$ 1158-1165. (doi:10.2337/diabetes.50.5.1158)

Odegaard JI, Ricardo-Gonzalez RR, Goforth MH, Morel CR, Subramanian V, Mukundan L, Red Eagle A, Vats D, Brombacher F, Ferrante AW et al. 2007 Macrophage-specific PPAR $\gamma$ controls alternative activation and improves insulin resistance. Nature $\mathbf{4 4 7}$ 1116-1120. (doi:10.1038/nature05894)

Ohshima T, Koga H \& Shimotohno K 2004 Transcriptional activity of peroxisome proliferator-activated receptor $\gamma$ is modulated by SUMO-1 modification. Journal of Biological Chemistry 279 29551-29557. (doi:10.1074/jbc.M403866200)

Okamura M, Kudo H, Wakabayashi K, Tanaka T, Nonaka A, Uchida A, Tsutsumi S, Sakakibara I, Naito M, Osborne TF et al. 2009 COUP-TFII acts downstream of $\mathrm{Wnt} / \beta$-catenin signal to silence PPAR $\gamma$ gene expression and repress adipogenesis. PNAS 106 5819-5824. (doi:10.1073/pnas.0901676106)

Okuno A, Tamemoto H, Tobe K, Ueki K, Mori Y, Iwamoto K, Umesono K, Akanuma Y, Fujiwara T, Horikoshi H et al. 1998 Troglitazone increases the number of small adipocytes without the change of white adipose tissue mass in obese Zucker rats. Journal of Clinical Investigation 101 1354-1361. (doi:10.1172/JCI1235)

Park SW, Hu X, Gupta P, Lin YP, Ha SG \& Wei LN 2007 SUMOylation of Tr2 orphan receptor involves Pml and fine-tunes Oct4 expression in stem cells. Nature Structural \& Molecular Biology 14 68-75. (doi:10.1038/ nsmb1185)

Pascual G, Fong AL, Ogawa S, Gamliel A, Li AC, Perissi V, Rose DW, Willson TM, Rosenfeld MG \& Glass CK 2005 A SUMOylation-dependent pathway mediates transrepression of inflammatory response genes by PPAR- $\gamma$. Nature 437 759-763. (doi:10.1038/nature03988)

Philips JC, Petite C, Willi JP, Buchegger F \& Meier CA 2004 Effect of peroxisome proliferator-activated receptor $\gamma$ agonist, rosiglitazone, on dedifferentiated thyroid cancers. Nuclear Medicine Communications 25 1183-1186. (doi:10.1097/00006231-200412000-00005)

Picard F, Géhin M, Annicotte J-S, Rocchi S, Champy M-F, O'Malley BW, Chambon P \& Auwerx J 2002 SRC-1 and TIF2 control energy balance between white and brown adipose tissues. Cell 111 931-941. (doi:10. 1016/S0092-8674(02)01169-8)

Postic C, Dentin R \& Girard J 2004 Role of the liver in the control of carbohydrate and lipid homeostasis. Diabetes \& Metabolism $30398-408$. (doi:10.1016/S1262-3636(07)70133-7)

Powell WS 2003 15-Deoxy- $\Delta 12,14-\mathrm{PGJ}_{2}$ : endogenous PPAR $\gamma$ ligand or minor eicosanoid degradation product? Journal of Clinical Investigation 112 828-830. (doi:10.1172/JCI19796)

Puigserver P, Wu Z, Park CW, Graves R, Wright M \& Spiegelman BM 1998 A cold-inducible coactivator of nuclear receptors linked to adaptive thermogenesis. Cell 92 829-839. (doi:10.1016/S00928674(00)81410-5)

Qi C, Surapureddi S, Zhu YJ, Yu S, Kashireddy P, Rao MS \& Reddy JK 2003 Transcriptional coactivator PRIP, the peroxisome proliferator-activated receptor $\gamma(\operatorname{PPAR} \gamma)$-interacting protein, is required for PPAR $\gamma$-mediated adipogenesis. Journal of Biological Chemistry 278 25281-25284. (doi:10.1074/jbc.C300175200)

Quinn CE, Hamilton PK, Lockhart CJ \& McVeigh GE 2008

Thiazolidinediones: effects on insulin resistance and the cardiovascular system. British Journal of Pharmacology 153 636-645. (doi:10.1038/ sj.bjp.0707452)

Rahman MM, Miyamoto H, Lardy H \& Chang C 2003 Inactivation of androgen receptor coregulator ARA55 inhibits androgen receptor activity and agonist effect of antiandrogens in prostate cancer cells. PNAS 100 5124-5129. (doi:10.1073/pnas.0530097100)

Rangwala SM, Rhoades B, Shapiro JS, Rich AS, Kim JK, Shulman GI, Kaestner KH \& Lazar MA 2003 Genetic modulation of PPAR $\gamma$ phosphorylation regulates insulin sensitivity. Developmental Cell 5 657-663. (doi:10.1016/S1534-5807(03)00274-0)

Rasbach KA \& Schnellmann RG 2007 PGC-1 $\alpha$ over-expression promotes recovery from mitochondrial dysfunction and cell injury. Biochemical 
and Biophysical Research Communications 355 734-739. (doi:10.1016/ j.bbrc.2007.02.023)

Ristow M, Muller-Wieland D, Pfeiffer A, Krone W \& Kahn CR 1998 Obesity associated with a mutation in a genetic regulator of adipocyte differentiation. New England Journal of Medicine 339 953-959. (doi:10.1056/NEJM199810013391403)

Schiltz RL \& Nakatani Y 2000 The PCAF acetylase complex as a potential tumor suppressor. Biochimica et Biophysica Acta 1470 M37-M53. (doi:10.1016/S0304-419X(99)00037-2)

Shao D, Rangwala SM, Bailey ST, Krakow SL, Reginato MJ \& Lazar MA 1998 Interdomain communication regulating ligand binding by PPAR- $\gamma$. Nature 396 377-380. (doi:10.1038/24634)

Shyr C-R, Hu Y-C, Kim E \& Chang C 2002 Modulation of estrogen receptormediated transactivation by orphan receptor TR4 in MCF-7 cells. Journal of Biological Chemistry 277 14622-14628. (doi:10.1074/ jbc.M110051200)

Shyr CR, Kang HY, Tsai MY, Liu NC, Ku PY, Huang KE \& Chang C 2009 Roles of testicular orphan nuclear receptors 2 and 4 in early embryonic development and embryonic stem cells. Endocrinology 150 2454-2462. (doi:10.1210/en.2008-1165)

Staels B \& Fruchart J-C 2005 Therapeutic roles of peroxisome proliferatoractivated receptor agonists. Diabetes 54 2460-2470. (doi:10.2337/ diabetes.54.8.2460)

Steppan CM, Bailey ST, Bhat S, Brown EJ, Banerjee RR, Wright CM, Patel HR, Ahima RS \& Lazar MA 2001 The hormone resistin links obesity to diabetes. Nature 409 307-312. (doi:10.1038/35053000)

Subramanian V, Golledge J, Ijaz T, Bruemmer D \& Daugherty A 2010 Pioglitazone-induced reductions in atherosclerosis occur via smooth muscle cell-specific interaction with PPAR $\gamma$. Circulation Research 107 953-958. (doi:10.1161/CIRCRESAHA.110.219089)

Takahashi Y, Ohoka N, Hayashi H \& Sato R 2008 TRB3 suppresses adipocyte differentiation by negatively regulating PPAR $\gamma$ transcriptional activity. Journal of Lipid Research 49 880-892. (doi:10.1194/ jlr.M700545-JLR200)

Tan NS, Michalik L, Desvergne B \& Wahli W 2005 Multiple expression control mechanisms of peroxisome proliferator-activated receptors and their target genes. Journal of Steroid Biochemistry and Molecular Biology 93 99-105. (doi:10.1016/j.jsbmb.2004.12.025)

Tontonoz P, Hu E, Graves RA, Budavari AI \& Spiegelman BM $1994 a$ mPPAR $\gamma 2$ : tissue-specific regulator of an adipocyte enhancer. Genes and Development 8 1224-1234. (doi:10.1101/gad.8.10.1224)

Tontonoz P, Hu E \& Spiegelman BM 1994b Stimulation of adipogenesis in fibroblasts by PPAR $\gamma 2$, a lipid-activated transcription factor. Cell 79 1147-1156. (doi:10.1016/0092-8674(94)90006-X)

Tontonoz P, Nagy L, Alvarez JG, Thomazy VA \& Evans RM 1998 PPAR $\gamma$ promotes monocyte/macrophage differentiation and uptake of oxidized LDL. Cell 93 241-252. (doi:10.1016/S0092-8674(00)81575-5)

Tsai Y-S \& Maeda N 2005 PPAR $\gamma$ : a critical determinant of body fat distribution in humans and mice. Trends in Cardiovascular Medicine $\mathbf{1 5}$ 81-85. (doi:10.1016/j.tcm.2005.04.002)

Unger RH \& Orci L 2001 Diseases of liporegulation: new perspective on obesity and related disorders. FASEB Journal 15 312-321. (doi:10.1096/ fj.00-0590)

Uryu S, Harada J, Hisamoto M \& Oda T 2002 Troglitazone inhibits both post-glutamate neurotoxicity and low-potassium-induced apoptosis in cerebellar granule neurons. Brain Research 924 229-236. (doi:10.1016/ S0006-8993(01)03242-5)

Vandewalle B, Moerman E, Lefebvre B, Defrance F, Gmyr V, Lukowiak B, Kerr Conte J \& Pattou F 2008 PPAR $\gamma$-dependent and -independent effects of rosiglitazone on lipotoxic human pancreatic islets. Biochemical and Biophysical Research Communications 366 1096-1101. (doi:10.1016/j.bbrc.2007.12.088)

Ventura-Clapier R, Garnier A \& Veksler V 2008 Transcriptional control of mitochondrial biogenesis: the central role of PGC-1 $\alpha$. Cardiovascular Research 79 208-217. (doi:10.1093/cvr/cvn098)

http://erc.endocrinology-journals.org DOI: 10.1530/ERC-13-0529
(C) 2014 Society for Endocrinology Printed in Great Britain
Verrier E, Wang L, Wadham C, Albanese N, Hahn C, Gamble JR, Chatterjee VK, Vadas MA \& Xia P 2004 PPAR $\gamma$ agonists ameliorate endothelial cell activation via inhibition of diacylglycerol-protein kinase C signaling pathway: role of diacylglycerol kinase. Circulation Research 94 1515-1522. (doi:10.1161/01.RES.0000130527. 92537.06)

Vidal-Puig A, Jimenez-Linan M, Lowell BB, Hamann A, Hu E, Spiegelman B, Flier JS \& Moller DE 1996 Regulation of PPAR $\gamma$ gene expression by nutrition and obesity in rodents. Journal of Clinical Investigation $\mathbf{9 7}$ 2553-2561. (doi:10.1172/JCI118703)

Waite KJ, Floyd ZE, Arbour-Reily P \& Stephens JM 2001 Interferon- $\gamma$ induced regulation of peroxisome proliferator-activated receptor $\gamma$ and STATs in adipocytes. Journal of Biological Chemistry 276 7062-7068. (doi:10.1074/jbc.M007894200)

Wang C, Fu M, D'Amico M, Albanese C, Zhou JN, Brownlee M, Lisanti MP, Chatterjee VK, Lazar MA \& Pestell RG 2001 Inhibition of cellular proliferation through $\mathrm{I} \kappa \mathrm{B}$ kinase-independent and peroxisome proliferator-activated receptor $\gamma$-dependent repression of cyclin D1. Molecular and Cellular Biology 21 3057-3070. (doi:10.1128/MCB.21.9. 3057-3070.2001)

Wang L, Shao YY \& Ballock RT 2005 Peroxisome proliferator activated receptor- $\gamma(\operatorname{PPAR} \gamma)$ represses thyroid hormone signaling in growth plate chondrocytes. Bone 37 305-312. (doi:10.1016/j.bone.2005.04.031)

Wei S, Yang HC, Chuang HC, Yang J, Kulp SK, Lu PJ, Lai MD \& Chen CS 2008 A novel mechanism by which thiazolidinediones facilitate the proteasomal degradation of cyclin D1 in cancer cells. Journal of Biological Chemistry 283 26759-26770. (doi:10.1074/jbc. M802160200)

Willson TM \& Wahli W 1997 Peroxisome proliferator-activated receptor agonists. Current Opinion in Chemical Biology 1 235-241. (doi:10.1016/ S1367-5931(97)80015-4)

Wood RJ 2008 Vitamin D and adipogenesis: new molecular insights. Nutrition Reviews 66 40-46. (doi:10.1111/j.1753-4887.2007.00004.x)

Wu Z, Puigserver P, Andersson U, Zhang C, Adelmant G, Mootha V, Troy A, Cinti S, Lowell B, Scarpulla RC et al. 1999 Mechanisms controlling mitochondrial biogenesis and respiration through the thermogenic coactivator PGC-1. Cell 98 115-124. (doi:10.1016/S00928674(00)80611-X)

Xie S, Lee YF, Kim E, Chen LM, Ni J, Fang LY, Liu S, Lin SJ, Abe J, Berk B et al. 2009 TR4 nuclear receptor functions as a fatty acid sensor to modulate CD36 expression and foam cell formation. PNAS 106 13353-13358. (doi:10.1073/pnas.0905724106)

Xie S, Ni J, Lee YF, Liu S, Li G, Shyr CR \& Chang C 2011 Increased acetylation in the DNA-binding domain of TR4 nuclear receptor by the coregulator ARA55 leads to suppression of TR4 transactivation. Journal of Biological Chemistry 286 21129-21136. (doi:10.1074/jbc. M110.208181)

Xu HE, Lambert MH, Montana VG, Parks DJ, Blanchard SG, Brown PJ Sternbach DD, Lehmann JM, Wisely GB, Willson TM et al. 1999 Molecular recognition of fatty acids by peroxisome proliferatoractivated receptors. Molecular Cell 3 397-403. (doi:10.1016/S10972765(00)80467-0)

Yamashita D, Yamaguchi T, Shimizu M, Nakata N, Hirose F \& Osumi T 2004 The transactivating function of peroxisome proliferator-activated receptor $\gamma$ is negatively regulated by SUMO conjugation in the aminoterminal domain. Genes to Cells 9 1017-1029. (doi:10.1111/j.13652443.2004.00786.x)

Yang Y, Wang X, Dong T, Kim E, Lin WJ \& Chang C 2003 Identification of a novel testicular orphan receptor-4 (TR4)-associated protein as repressor for the selective suppression of TR4-mediated transactivation. Journal of Biological Chemistry 278 7709-7717. (doi:10.1074/jbc. M207116200)

Yang X, Downes M, Yu RT, Bookout AL, He W, Straume M, Mangelsdorf DJ \& Evans RM 2006 Nuclear receptor expression links the circadian clock to metabolism. Cell 126 801-810. (doi:10.1016/j.cell.2006. 06.050) 
Yang CC, Wang YC, Wei S, Lin LF, Chen CS, Lee CC, Lin CC \& Chen CS 2007 Peroxisome proliferator-activated receptor $\gamma$-independent suppression of androgen receptor expression by troglitazone mechanism and pharmacologic exploitation. Cancer Research 67 3229-3238. (doi:10.1158/0008-5472.CAN-06-2759)

Yang DR, Lin SJ, Ding XF, Miyamoto H, Messing E, Li LQ, Wang N \& Chang C 2013 Higher expression of peroxisome proliferator-activated receptor $\gamma$ or its activation by agonist thiazolidinedione-rosiglitazone promotes bladder cancer cell migration and invasion. Urology $\mathbf{8 1}$ 1109-e1101-1106. (doi:10.1016/j.urology.2012.12.027)

Yu C, Markan K, Temple KA, Deplewski D, Brady MJ \& Cohen RN 2005 Nuclear receptor corepressors NCoR and SMRT decrease peroxisome proliferator-activated receptor $\gamma$ transcriptional activity and repress 3T3-L1 adipogenesis. Journal of Biological Chemistry 280 13600-13605. (doi:10.1074/jbc.M409468200)

Zhang R \& Zheng F 2008 PPAR- $\gamma$ and aging: one link through Klotho? Kidney International 74 702-704. (doi:10.1038/ki.2008.382)

Zhang B, Berger J, Zhou G, Elbrecht A, Biswas S, White-Carrington S, Szalkowski D \& Moller DE 1996 Insulin- and mitogen-activated protein kinase-mediated phosphorylation and activation of peroxisome proliferator-activated receptor $\gamma$. Journal of Biological Chemistry 271 31771-31774. (doi:10.1074/jbc.271.50.31771)
Zhang Y, Chen YT, Xie S, Wang L, Lee YF, Chang SS \& Chang C 2007 Loss of testicular orphan receptor 4 impairs normal myelination in mouse forebrain. Molecular Endocrinology 21 908-920. (doi:10.1210/ me.2006-0219)

Zhang H, Li Y, Fan Y, Wu J, Zhao B, Guan Y, Chien S \& Wang N 2008 Klotho is a target gene of PPAR- $\gamma$. Kidney International 74 732-739. (doi:10.1038/ki.2008.244)

Zhao X, Ou Z, Grotta JC, Waxham N \& Aronowski J 2006 Peroxisomeproliferator-activated receptor- $\gamma(\operatorname{PPAR} \gamma)$ activation protects neurons from NMDA excitotoxicity. Brain Research 1073-1074 460-469. (doi:10.1016/j.brainres.2005.12.061)

Zhou XE, Suino-Powell KM, Xu Y, Chan CW, Tanabe O, Kruse SW, Reynolds R, Engel JD \& Xu HE 2011 The orphan nuclear receptor TR4 is a vitamin A-activated nuclear receptor. Journal of Biological Chemistry 286 2877-2885. (doi:10.1074/jbc.M110.168740)

Zhu Y, Alvares K, Huang Q, Rao MS \& Reddy JK 1993 Cloning of a new member of the peroxisome proliferator-activated receptor gene family from mouse liver. Journal of Biological Chemistry 268 26817-26820.

Zhu Y, Qi C, Calandra C, Rao MS \& Reddy JK 1996 Cloning and identification of mouse steroid receptor coactivator-1 (mSRC-1), as a coactivator of peroxisome proliferator-activated receptor $\gamma$. Gene Expression 6 185-195.

Received in final form 10 February 2014

Accepted 25 February 2014

Made available online as an Accepted Preprint

28 February 2014
(C) 2014 Society for Endocrinology Printed in Great Britain
Published by Bioscientifica Ltd. 